\title{
Hormone Receptor Loss in Breast Cancer: Molecular Mechanisms, Clinical Settings, and Therapeutic Implications
}

\author{
Emma Zattarin ${ }^{1,+}{ }^{,}$Rita Leporati ${ }^{1,+}+\mathbb{D}$, Francesca Ligorio ${ }^{1}$, Riccardo Lobefaro ${ }^{1}{ }^{1}$, \\ Andrea Vingiani ${ }^{1}$ (D), Giancarlo Pruneri ${ }^{1,2, \ddagger}$ and Claudio Vernieri ${ }^{1,3, *, \ddagger}$ (D) \\ 1 Fondazione IRCCS Istituto Nazionale dei Tumori, Via G. Venezian 1, 20133 Milan, Italy; \\ emma.zattarin@istitutotumori.mi.it (E.Z.); rita.leporati@istitutotumori.mi.it (R.L.); \\ francesca.ligorio@istitutotumori.mi.it (F.L.); riccardo.lobefaro@istitutotumori.mi.it (R.L.); \\ andrea.vingiani@istitutotumori.mi.it (A.V.); giancarlo.pruneri@istitutotumori.mi.it (G.P.) \\ Department of Oncology and Haematology, University of Milan, Via Festa del Perdono 7, 20122 Milan, Italy \\ IFOM, The FIRC Institute of Molecular Oncology, Via Adamello 16, 20139 Milan, Italy \\ Correspondence: claudio.vernieri@istitutotumori.mi.it; Tel.: +39-02-2390-3650 \\ + These authors contributed equally. \\ $\ddagger$ These authors contributed equally.
}

Received: 3 November 2020; Accepted: 5 December 2020; Published: 9 December 2020

\begin{abstract}
Hormone receptor-positive breast cancer (HR+ BC) accounts for approximately $75 \%$ of new BC diagnoses. Despite the undisputable progresses obtained in the treatment of $\mathrm{HR}+\mathrm{BC}$ in recent years, primary or acquired resistance to endocrine therapies still represents a clinically relevant issue, and is largely responsible for disease recurrence after curative surgery, as well as for disease progression in the metastatic setting. Among the mechanisms causing primary or acquired resistance to endocrine therapies is the loss of estrogen/progesterone receptor expression, which could make BC cells independent of estrogen stimulation and, consequently, resistant to estrogen deprivation or the pharmacological inhibition of estrogen receptors. This review aims at discussing the molecular mechanisms and the clinical implications of HR loss as a result of the therapies used in the neoadjuvant setting or for the treatment of advanced disease in $\mathrm{HR}+\mathrm{BC}$ patients.
\end{abstract}

Keywords: breast cancer; hormone receptors; conversion; intratumor heterogeneity; clonal selection; endocrine therapies; (neo)adjuvant therapy; tumor recurrences; re-characterization

\section{Introduction}

Estrogen receptor alpha-positive $(\mathrm{ER} \alpha+)$ breast cancer $(\mathrm{BC})$ accounts for approximately $75 \%$ of all $\mathrm{BC}$ diagnoses [1]. About half of all ER $\alpha+\mathrm{BC}$ also express the progesterone receptor (PgR), whose gene is under the transcriptional control of $\mathrm{ER} \alpha$ and its ligands (e.g., estradiol or E2) [2]. ER $\alpha+/ \operatorname{PgR}+\mathrm{BC}$ is also referred to as hormone receptor (HR)-positive BC.

By binding and activating ER $\alpha, E 2$ regulates the growth and differentiation of both normal mammalian cells and $\mathrm{HR}+\mathrm{BC}$ cells. Once ER $\alpha$ binds to estrogens, it homodimerizes and activates genomic and non-genomic signaling pathways that stimulate cancer cell growth and proliferation [3]. $E R \beta$ is a second isoform of ER, with distinct biological roles when compared with ER $\alpha$. The effect of $\mathrm{ER} \beta$ on the regulation of the gene expression has been less investigated, but several reports support its role in counteracting the ER $\alpha$-induced stimulation of BC cell proliferation [4-6]. ER $\alpha$ and $\operatorname{Er} \beta$ can also heterodimerize, consistent with the role of ER $\beta$ in modulating ER $\alpha$ activity [6,7]. HR status is a well-established prognostic and predictive factor in BC patients. Among the different BC subgroups, $\mathrm{HR}+\mathrm{BC}$ is characterized by lower growth and proliferation rates of cancer cells, as well as by 
longer disease-free survival (DFS) and overall survival (OS) after surgery, in addition to better OS in the metastatic disease setting. Even more importantly, HR expression is a predictive biomarker of the clinical benefit of endocrine therapies (ETs) in both limited-stage and advanced disease settings. Indeed, the assessment of the ER $\alpha / P g R$ expression by immunohistochemistry (IHC) is of the outmost importance in order to guide the choice of pharmacological therapies in all disease settings [8]. On the other hand, $\mathrm{HR}+\mathrm{BC}$ is generally less sensitive to cytotoxic chemotherapy, including neoadjuvant chemotherapy (NAC), when compared with HER2-positive (HER2+) BC and triple-negative breast cancer (TNBC) $[9,10]$.

As HR+ BC depends on E2-induced or constitutive ER $\alpha$ activation for the stimulation of tumor cell growth and proliferation, different ETs resulting in the inhibition of ER $\alpha$ signaling have proven to be effective in the treatment of $\mathrm{HR}+\mathrm{BC}$ patients in both adjuvant and advanced disease settings. In particular, the selective estrogen receptor modulator (SERM) tamoxifen; the selective estrogen receptor downregulator (SERD) fulvestrant; or compounds that interfere with estrogen synthesis, such as aromatase inhibitors or ovarian suppression through luteinizing hormone-releasing hormone (LHRH) agonists, have become standard-of-care therapies in patients with HR+ BC in all clinical settings [11]. Despite the efficacy of these ETs, primary or acquired resistance of HR+ BC cells to ETs is a common event, especially in the advanced disease setting, where it is largely responsible for the failure of available ETs and, ultimately, for the death of the majority of BC patients.

Several molecular mechanisms have been proposed to mediate primary or acquired resistance to ETs in HR+ BC. These mechanisms include mutations in the ESR1 gene, which encodes ER $\alpha$, or alterations in the genes of the mitogen activated protein kinase (MAPK) pathway (e.g., activating ERBB2 mutations and NF1 loss-of-function mutations) or ESR1 transcriptional regulators, such as MYC (human homolog of the avian viral myelocytomatosis gene) [12]. Interestingly, some of these genomic mechanisms of resistance could be targeted by selective inhibitors that are already available for clinical use in other contexts [13]. Another potential mechanism of resistance to ETs in HR+ BC consists of the loss of ER $\alpha$ expression, which could make cancer cells independent of E2- and ER $\alpha$ - induced stimulation of tumor cell growth and proliferation. While several studies have characterized the genomic mechanisms of $\mathrm{HR}+\mathrm{BC}$ cell resistance to ETs and their clinical consequences, the molecular mechanisms underneath HR conversion from HR+ to HR-negative (HR-) status, as well as their impact on patient prognosis and on the choice of therapeutic strategies, remain much less explored. This manuscript aims at reviewing and discussing (a) the available evidence regarding the molecular mechanisms that are responsible for HR status conversion in HR+ BC patients, (b) the clinical scenarios in which this phenomenon can occur, and (c) the therapeutic implications of HR status conversion in different clinical settings.

\section{Molecular Mechanisms Underlying Loss of HR Expression in BC Cells}

It has been proposed that most $\mathrm{ER} \alpha-$ negative $(\mathrm{ER} \alpha-) \mathrm{BCs}$ arise from $\mathrm{ER} \alpha+\mathrm{BC}$ cells that subsequently loose ER $\alpha$ expression. Therefore, the identification of the mechanisms responsible for the changes in HR status could be helpful in the discovery of potentially effective therapeutic strategies to target ER $\alpha$-BC cells [14] (Figure 1).

One major limitation of the molecular studies assessing HR status conversion is the fact that this phenomenon can occur in different phases of $\mathrm{BC}$ progression and, as a consequence, it could be driven by different mechanisms $[15,16]$. In particular, it remains unclear whether HR status conversion occurs spontaneously, or as a result of the selective pressure of estrogen deprivation in the patient blood or in the tumor microenvironment, or, finally, as an adaptive response to specific pharmacological treatments. Of note, not only estrogen deprivation or anti-estrogen compounds, but also cytotoxic agents, have been shown to modulate HR expression in BC cells $[17,18]$. 


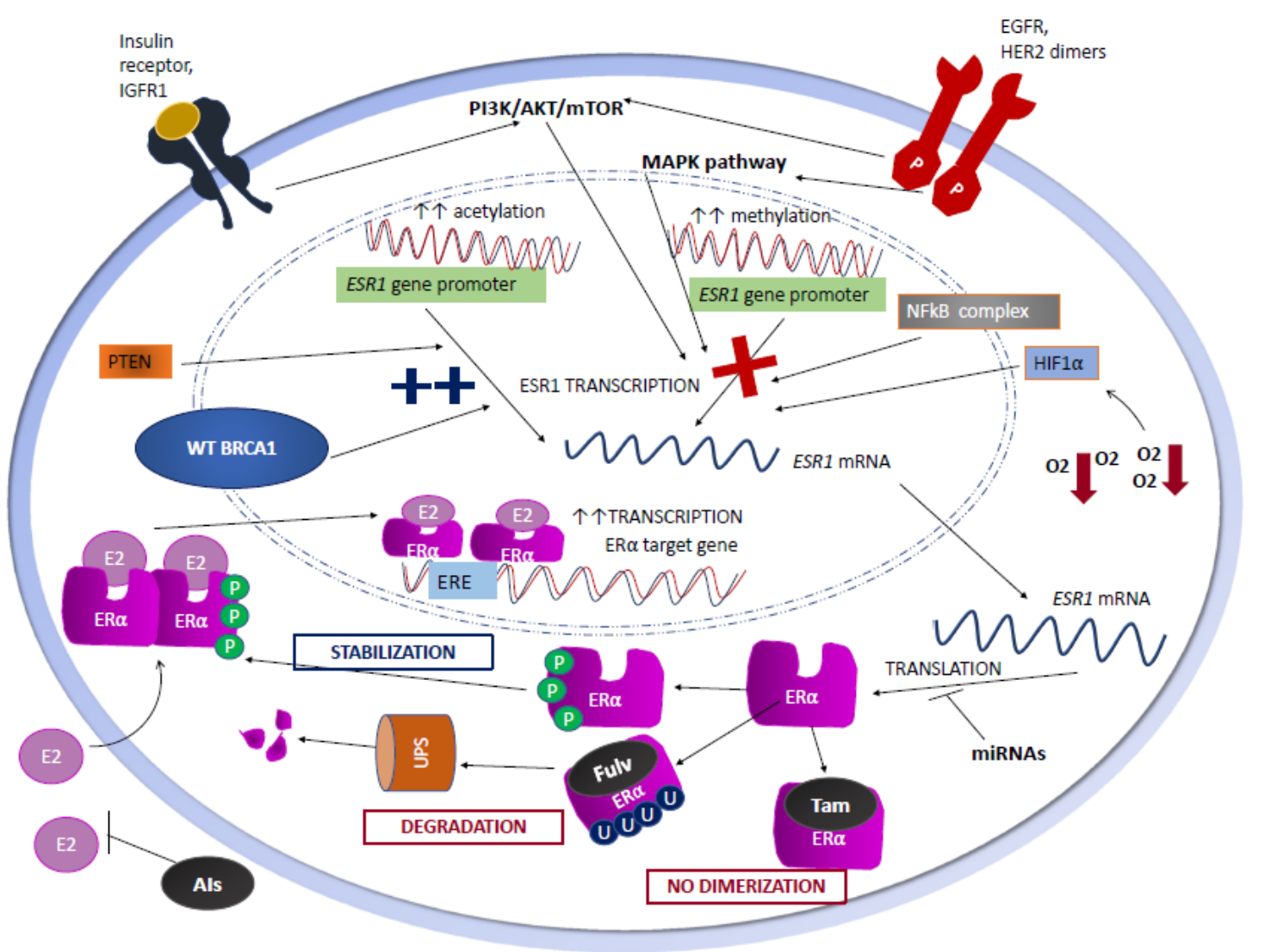

Figure 1. Mechanisms that regulate ESR1 transcription, ESR1 mRNA translation, and ER $\alpha$ post-translational modifications in HR+ BC cells. BRCA1: Breast Cancer Type 1 susceptibility protein; E2: estradiol; ER $\alpha$ : estrogen receptor alpha; ERE: estrogen responsive element; AIs: aromatase inhibitors; Fulv: fulvestrant; miRNAs: microRNAs; P: phosphate group; PTEN: phosphatase and tensin homolog; Tam: tamoxifen; U: ubiquitin; UPS: ubiquitin proteasome system.

\subsection{Genetic Mechanisms}

ESR1 gene is located on chromosome 6q25.1, and spans eight exons and two non-coding regions over more than $140 \mathrm{~Kb}$ of DNA. ER $\alpha$ is a nuclear receptor protein, whose structure includes the $\mathrm{N}$-terminal activation function 1 (AF1) domain; the DNA-binding domain (DBD) with two zinc finger motifs; the C-terminal domains, namely the 12-helical ligand-binding domain (LBD), which interacts with estrogens, and the ligand-dependent activation function 2 (AF2) domain, which is responsible for ligand-dependent $\operatorname{Er} \alpha$ transactivation, including the cofactor-binding groove to which cofactors are recruited when the ER $\alpha$ becomes activated; and the flexible hinge domain, or D region, which contains the nuclear localization signal (NLS) and links the C-domain to the AF2 domain [19]. Two forms of Er $\alpha$ exist: the estrogen-occupied form, which is associated with nuclear chromatin and stimulates gene transcription, and the unoccupied form, which is loosely associated with nuclear chromatin and is, therefore, more easily extracted from the nuclei during hypotonic lysis of the cells [20,21].

When $\mathrm{E} 2$ binds $\mathrm{ER} \alpha$, it stimulates $\mathrm{ER} \alpha$ homodimerization and binding to specific DNA regions known as estrogen responsive elements (EREs) within the enhancers and promoters of target genes (Figure 1) [22]. At the same time, AF-1 and AF-2 domains recruit coregulators that the remodel chromatin structure [23]. Through these mechanisms, ER $\alpha$ homodimers activate the transcription of the genes implicated in cell growth, proliferation, and signaling.

When stimulated by E2-independent signals, such as AF1 phosphorylation by growth factor-dependent kinases or the palmitoylation of $\mathrm{Cys}^{447}$ in the LBD, ER $\alpha$ also sustains intracellular molecular signaling through non-genomic mechanisms [24]. In fact, ER $\alpha$ localization is dynamic, and ER $\alpha$ shuttles between the nucleus and the cytoplasm, but it can also be detected in the cancer cells' 
plasma membrane, where it directly interacts with several oncogenic proteins and stimulates oncogenic signaling pathways. Within the plasma membrane, ER $\alpha$ may form homodimers or couple with other proteins, such as caveolins or flotillins in the lipid rafts [25], where ER $\alpha$ transactivates the epidermal growth factor receptor (EGFR), HER2 receptor, insulin-like growth factor receptor I (IGFR I), the p85 regulatory subunit of phosphatidylinositol 3-kinase (PI3K), and G-proteins, relaying downstream proliferative and survival signals via mitogen-activated protein kinase (MAPK) and AKT [26].

Several studies have explored genetic ESR1 alterations, such as gene mutations resulting in a constitutively active $\mathrm{ER} \alpha$, as a cause of endocrine resistance of $\mathrm{HR}+\mathrm{BC}$ cells; on the other hand, genetic alterations leading to a loss of ER $\alpha$ expression have been much less investigated [27]. Interestingly, while the loss of heterozygosity ( $\mathrm{LOH}$ ) of ESR1 occurs in $18 \%$ of $\mathrm{BCs}$, the most commonly detected ESR1 alterations, i.e., gene deletions, insertions, rearrangements, or polymorphisms, are not commonly associated with a loss of ER $\alpha$ expression/activity. In particular, only a few studies support the development of $\mathrm{BC}$ resistance to ETs as a result of a lack in ER $\alpha$ function induced by the homozygous deletion of the ESR1 gene or $\mathrm{LOH}$ with inactivating mutations in the remaining allele [28-30].

The PGR gene is located on chromosome 11q22-23, and spans eight exons over more than $90 \mathrm{~kb}$ [31]. It exists in two isoforms, $\mathrm{A}$ and $\mathrm{B}$, which originate from two distinct transcription initiation sites and bear different biological functions; while PgR-A is a transcriptional repressor of both ER $\alpha$ and PgR-B, the latter acts as a transcription activator. Therefore, while PgR expression is induced by ER $\alpha, \operatorname{PgR}$ binds ER $\alpha$ to modulate its signaling [32]. As in the case of the ESR1 gene, PGR is also rarely mutated in primary BC [33]; in addition, the correlation between $P G R$ mutations and the loss of PgR protein expression remains uncertain. On the other hand, $\mathrm{LOH}$ of the $P G R$ gene occurs in approximately $18-40 \%$ of ER $\alpha+$ BCs [34], and it has been associated with a loss of PgR protein expression [34].

\subsection{Epigenetic Mechanisms}

ESR1 and PGR promoters are subjected to cyclic methylation/demethylation of CpG dinucleotides, which, in turn, can modulate ER $\alpha$ and PgR levels and the biological signaling downstream of $\mathrm{ER} \alpha / \mathrm{PgR}$ in human HR+ BC cells [35-38]. Upon ESR1 promoter methylation, several transcription factors, such as AP2, cannot be recruited to the ESR1 DNA locus any longer, thus resulting in the inhibition of ESR1 transcription (Figure 1) [38]. Zinc-finger E-box binding homebox 1 (ZEB1), an important member of the zinc-finger-homeodomain transcription factor family, has been shown to repress ESR1 transcription by forming a ZEB1/DNA methyltransferase (DNMT)3B/histone deacetylase 1 (HDAC 1) complex on the ESR1 promoter, finally leading to its hypermethylation (Figure 1) [39]. Similarly, an increase in histone deacetylation has been shown to limit ESR1 transcription by condensing the nucleosome structure [37].

In HR+ BC cells, the loss of ER $\alpha$-mediated signaling also results in the repression of PGR gene transcription, a process that involves the recruitment of polycomb repressors and histone deacetylases to the PGR gene promoter, as well as PGR promoter methylation (Figure 2) [40]. Interestingly, one work showed that three methylation-sensitive restriction sites in the $P G R$ gene $C p G$ islands are not methylated in normal breast and in PgR+ BC specimens, but they are hypermethylated in approximately $40 \%$ of PgR- human BCs. These data suggest that the hypermethylation of PGR gene CpG islands is associated with a lack of PgR gene expression in a significant fraction of human BCs [41]. 


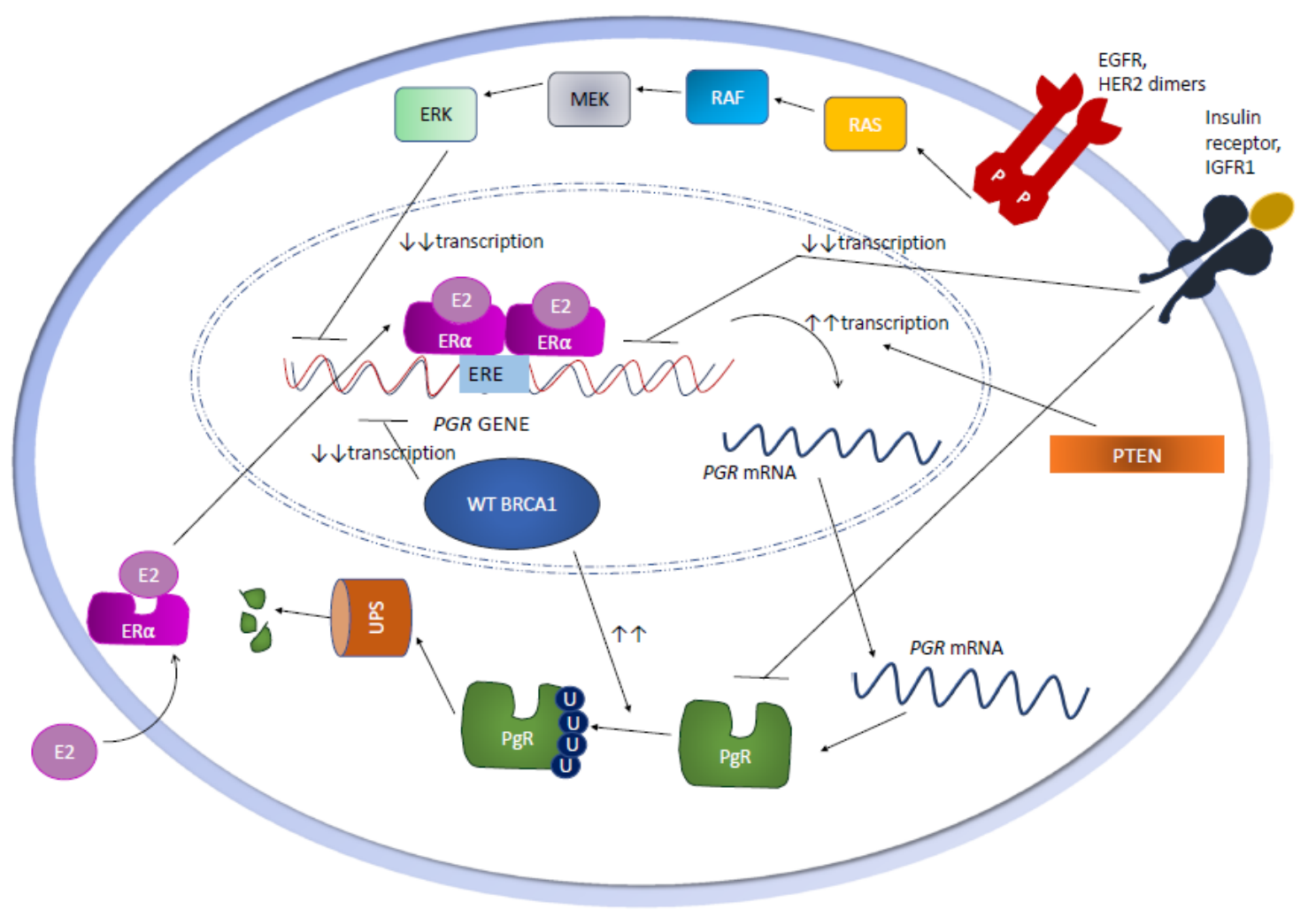

Figure 2. Mechanisms that regulate $P G R$ transcription, $P G R$ mRNA translation and PgR post-translational modifications in HR+ BC cells. BRCA1: Breast Cancer Type 1 susceptibility protein; E2: estradiol; ER $\alpha$ : estrogen receptor alpha; ERE: estrogen responsive element; PTEN: Phosphatase and tensin homolog; U: ubiquitin; UPS: ubiquitin proteasome system; WT: wild type.

\subsection{Growth Factor Signaling}

Several studies have shown a negative correlation between ER $\alpha$ expression/activation and the activation status of the PI3K/AKT/mTORC1 and MAPK signaling cascades. In the study by Perren A. et al., loss of phosphatase and tensin homolog (PTEN), an inhibitor of the PI3K/AKT/mTORC1 axis, was correlated with the loss of both ER $\alpha$ and PgR expressions in primary BC specimens (Figure 1), while Garcia J.M. et al. showed that LOH of the PTEN gene, which occurs in approximately $30-40 \%$ of sporadic BCs, is associated with a higher tumor histologic grade and loss of PgR, but not of ER $\alpha$ expression [42,43]. Moreover, short-term treatment with insulin-like growth factor-I (IGF-I), epidermal growth factor (EGF), and heregulin, induced the downregulation of PGR mRNA and PgR protein levels in BC cell lines [44].

Oh A.S. et al. showed that the hyperactivation of MAPK resulting from the overexpression of EGFR or c-erbB-2 results in ER $\alpha$ down-regulation (1) [45]. In particular, EGFR expression in human BC cell lines and in human BC specimens is inversely correlated with ER $\alpha$ expression, mainly as a result of the ER $\alpha$-induced down-regulation of EGFR mRNA levels [46]. HER2/neu overexpression and HER2-mediated signaling have also been associated with the down-regulation of ER $\alpha$ and PgR expression. Approximately half of HER2+ BCs express ER $\alpha$, whereas only $~ 10 \%$ of ER $\alpha+B C s$ show HER2 overexpression [47]. HER2/neu overexpression/aberrant activation causes HR downregulation through both the PI3K/AKT/mTORC1 pathway, e.g., via AKT-mediated reduction of FOXO3a protein expression, and through the p42/44 MAPK pathway [45-48]. This could partly explain why ER $\alpha+/$ HER2 + BCs tend to express lower ER $\alpha$ levels when compared with ER $\alpha+/ H E R 2$ negative $\mathrm{BCs}$, and they more frequently show relative resistance to ETs in the absence of concomitant HER2 inhibition [49]. Consistently, Creighton C.J. et al. showed that ER $\alpha+$ PgR- BC cell lines overexpressing EGFR or constitutively active erbB-2 or RAF have a significantly lower expression of 
the ESR1 gene [50]. A MAPK gene expression signature obtained from BC cell lines and validated in mRNA profiles of human BC datasets confirmed that MAPK hyperactivation profiles are enriched in ER $\alpha-$ BCs. Interestingly, the MAPK pathway-mediated downregulation of ER $\alpha$ expression has been demonstrated to be reversible and dynamic, and MAPK pathway inhibition results in ER $\alpha$ re-expression in MCF-7 cells.

Nuclear factor-kB complex (NFkB), a ubiquitously expressed family of inducible transcription factors, can also contribute to ER $\alpha$ down-regulation (Figure 1). In ER $\alpha$ - BC cell lines, NFkB is often found to be constitutively active, while its activation status is intermediate in ER $\alpha+/ H E R 2+B C$ cell lines; finally, a low or absent NFkB expression is typically found in ER $\alpha+/ H E R 2$ negative human BC cell lines [51]. In 81 primary human BC tissue samples, a higher NFkB activity is significantly correlated with lower ER $\alpha$ expression levels [52]. NFkB enhanced activation in ER $\alpha$ - BCs could be a consequence of MAPK hyperactivation [53] or, alternatively, it could depend on the PI3K/AKT/mTORC1 signaling pathway [54].

These data are consistent with the observation that the aberrant activation of growth factor signaling, including the MAPK and PI3K/AKT/mTORC1 pathways, is a common finding in HRBC [55].

\subsection{Post-Transcriptional Regulation of ER Expression}

ESR1 gene transcription results in the synthesis of a mRNA molecule of $4.3 \mathrm{~kb}$ in length, with an extensive $3^{\prime}$ untranslated region (UTR) containing several regulatory elements, including long tracts of AU-rich sequences and 13 copies of AUUUA, which play a role in its destabilization through deadenylation and polyadenylase tail digestion [56]. Therefore, modifications of the ESR1 mRNA sequence and structure could affect the ribosomal translation of $E R \alpha$, but the mechanisms responsible for this phenomenon have not been fully elucidated yet [57].

Different microRNAs (miRNAs) interfere with ESR1 mRNA translation (Figure 1) and, as a consequence, with ER $\alpha$ and ER $\beta$ levels. For instance, miR-222/221, which targets ESR1 mRNA for degradation, has been found to be significantly higher in ER $\alpha$ - cells than in ER $\alpha+$ BC cells [58]. In addition, miR-206 has also been found to bind the $3^{\prime}$ UTR of ESR1 mRNA, while miR-92 targets the $3^{\prime}$ UTR of ER $\beta 1$ mRNA [59]. Finally, in the MCF-7 HR+ BC cell lines, miR-27a targets ZBTB10, a specificity protein that directly regulates ER $\alpha$ expression [60].

\subsection{Post-Translational Regulation of ER $\alpha$ Expression}

$\mathrm{ER} \alpha$ activity can also be affected by post-translational modifications, including ubiquitination and phosphorylation. Interestingly, while E2 binds to ER $\alpha$ and stimulates its homodimerization and activation, it also promotes $\mathrm{ER} \alpha$ polyubiquitination and degradation via the ubiquitin proteasome system (UPS). In addition, the binding of the E2-ER $\alpha$ complex to the EREs of the target genes leads to the recruitment of both coactivators of gene transcription and E3-ubiquitin ligases, thus balancing the E2-ER $\alpha$ complex transcriptional activity and ER $\alpha$ degradation/inhibition [61]. These regulatory mechanisms, which give rise to an incoherent feed-forward loop, self-limit the E2-induced stimulation of $E R \alpha$, and result in a fine modulation of the intensity and duration of E2-ER $\alpha$ signaling. Of note, ER $\alpha$ polyubiquitination-mediated degradation is exploited by selective endocrine therapies acting as SERDs, such as fulvestrant, and new oral molecules that are being investigated in HR+/HER2- BC patients with tumors that are refractory to standard ETs (Figure 1) [62]. It is important to note that, while SERDs directly induce $E R \alpha$ degradation, they do not directly suppress the ER $\alpha$ transcriptional activity, which is instead driven by the induction of a conformational change in the receptor that disrupts the integrity of the primary coactivator binding surface and competitively displaces estradiol $[63,64]$. Therefore, both intracellular signals and pharmacological treatments can affect the intracellular ER $\alpha$ levels and biological activity.

$\mathrm{ER} \alpha$ phosphorylation in different amino acidic residues modulates ER $\alpha$ ubiquitination. In BC cells grown in E2-containing media, SRC-induced phosphorylation of ER $\alpha$ in the Y537 residue induces the 
recruitment of E3-ubiquitin ligases, and the subsequent polyubiquitination and proteasome-mediated degradation of ER $\alpha$ [65]. Conversely, ER $\alpha$ phosphorylation by GSK3, LMTK3, and ABL stabilizes $\mathrm{ER} \alpha$ and promotes its activity as a transcription factor (Figure 1) [61]. Other proteins and mechanisms converge on ER $\alpha$ degradation via UPS. For instance, Mucin 1 (MUC1) acts as an ER $\alpha$ coactivator by stabilizing its binding to ERE promoters and by recruiting histone acetyl-transferases of the p160 family to promote ER $\alpha$-induced gene transcription [66]; consistently, MUC1-knock down in HR+ $\mathrm{BC}$ cells is associated with reduced ER $\alpha$ levels [61]. In addition, peptidyl prolyl isomerase1 (PIN1) prevents the interaction of the E3 ligase E6AP with ER $\alpha$ and, as a consequence, it inhibits ER $\alpha$ degradation [67]. The tumor suppressor retinoblastoma (RB) protein has also been shown to contribute to the post-translational regulation of $\mathrm{ER} \alpha$ in $\mathrm{BC}$ cell lines, through the interaction between the $N$-terminal domain of RB and DBD, and the hinge region of $E R \alpha$, the chaperone proteins HSP90 and p23 bind to ER $\alpha$ and protect it from UPS-induced degradation. In human and mouse BC cells, $R B$ knock-down was associated with significantly lower ER $\alpha$ protein levels, thus suggesting a possible role of RB loss in the establishment of a ER $\alpha$ - phenotype [68].

While ER $\alpha$ polyubiquitination promotes its degradation via the proteasome, $\mathrm{ER} \alpha$ monoubiquitination leads to ER $\alpha$ stabilization by preventing its polyubiquitination; the RNF31 protein, which associates to $\mathrm{ER} \alpha$ in the cytoplasm of $\mathrm{BC}$ cells and promotes its monoubiquitination, is responsible for increased $\mathrm{ER} \alpha$ levels and enhanced ER $\alpha$ activity [69].

Finally, ER $\alpha$ palmitoylation promotes ER $\alpha$ stabilization and its recruitment to the cell plasma membrane, where it activates oncogenic signaling through mechanisms that do not require a reprogramming of the gene expression. ER $\alpha$ mutations preventing palmitoylation were reported to be associated with ER $\alpha$ degradation [70].

\subsection{The Role of Hypoxia}

Hypoxia, defined as a suboptimal concentration of oxygen in the tumor microenvironment resulting from a combination of an excessive tumor growth rates and insufficient or aberrant tumor vascularization, has been crucially implicated in the stimulation of tumor cell growth, metabolic reprogramming, and metastasis [71]. Interestingly, one preclinical study showed that hypoxia reduces $\mathrm{ER} \alpha$ protein levels, but not ESR1 mRNA levels, in HR+ BC cell lines via the proteasome-dependent degradation of ER $\alpha$ and the HIF-1 $\alpha$-mediated repression of ESR1 gene transcription (Figure 1); however, data linking ER $\alpha$ expression to HIF-1 $\alpha$ signaling are still controversial [72-74].

\subsection{The Role of BRCA1}

Approximately $10-20 \%$ of $B C$ s arising in patients with pathogenetic germline $B R C A 1$ mutations express $E R \alpha$ [75]. ER $\alpha+B C$ s arising in BRCA1-mutated carriers typically show characteristics of biological and clinical aggressiveness, including a higher tumor grade and higher proliferation rates when compared with ER $\alpha+B C$ occurring in BRCA1 non-carriers [76]. In addition to its role in DNA damage response, BRCA1 is directly involved in regulating gene transcription in cancer cells, partly as a component of the RNA polymerase II holoenzyme complex via its interaction with RNA helicase A [77]. In the study by Hosey A.M. et al., wild-type BRCA1 was shown to directly activate the ESR1 gene transcription by binding to the ESR1 promoter and by recruiting Oct1 (Figure 1) [78]. As a consequence of the BRCA1-induced transcription of ESR1, several BCs arising in subjects carrying germline BRCA1 inactivating mutations might display a low ER $\alpha$ expression as a result of the loss of the BRCA1-mediated transcription of ESR1. However, also in subjects with wild-type germline $B R C A 1$, a progressive decrease of BRCA1 protein levels or reduced BRCA1 activation in BC cells as a result of genetic or epigenetic mechanisms, such as $B R C A 1$ gene $\mathrm{LOH}, B R C A 1$ promoter hypermethylation, or transcriptional repression, might be responsible for reduced ESR1 gene transcription and ER $\alpha$ protein levels [78]. Therefore, even during sporadic BC tumorigenesis, ER $\alpha$ expression levels might be progressively reduced in some patients as a result of a progressive reduction of BRCA1 expression/activity. Consistent with this hypothesis, BRCA1 mRNA expression levels have been shown to positively correlate with 
ESR1 mRNA levels in patients with sporadic BC, while reduced BRCA1 levels or activation, which can occur in sporadic BCs during tumor progression, or as a result of treatment-induced modifications of tumor biology, could directly impact ER $\alpha$ loss [79]. With regards to the PgR expression, wild type BRCA1regulates PgR levels by modulating the E3 ubiquitin ligase activity; in detail, BRCA1 promotes PgR protein ubiquitination and degradation, and, at the same time, targets the hormone-responsive regions (HRR) of the PgR target genes and induces chromatin silencing at PgR-regulated promoters via the BRCA1/BARD1 complex (Figure 2) [80].

\subsection{Intratumor Heterogeneity}

Loss of ER $\alpha$ and/or PgR expression in recurrent HR+ BC can result from the clonal selection of biologically heterogeneous primary or metastatic BC lesions during the course of ETs, i.e., under the selective pressure of reduced extracellular estrogens or the pharmacological inhibition of the ER $\alpha$ pathway (Figure 3) [81].

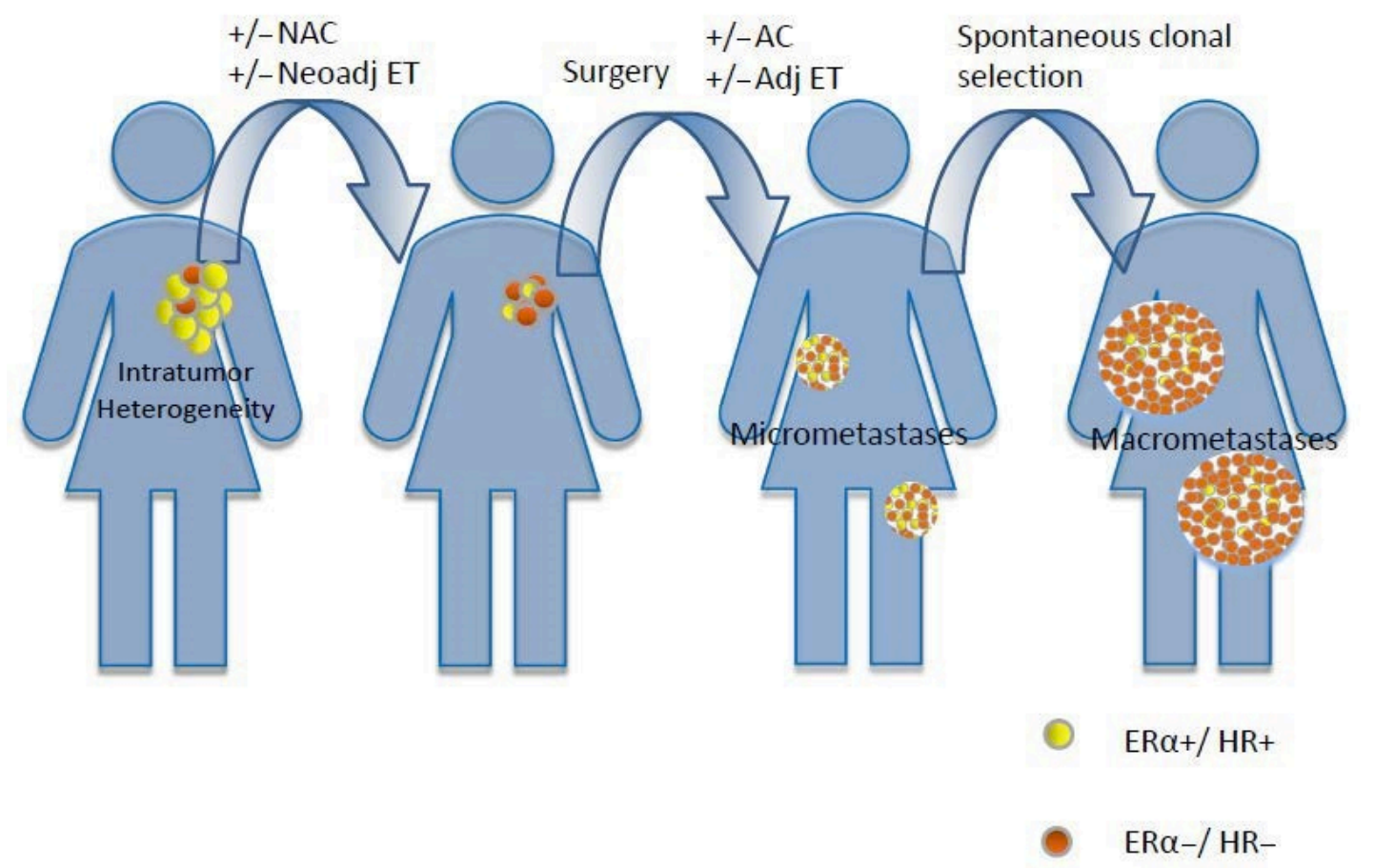

Figure 3. Presence of baseline tumor heterogeneity, with the coexistence of ER $\alpha+/ \mathrm{HR}+$ and ER $\alpha-/ \mathrm{HR}-$ clones and selective pressure of different treatments, which lead to the progressive selection of tumor lesions enriched for ER $\alpha-/ H R-$ cells. NAC: neoadjuvant chemotherapy; Neoadj ET: neoadjuvant endocrine therapy; AC: adjuvant chemotherapy; Adj ET: adjuvant endocrine therapy.

Intratumor heterogeneity exists in the presence of tumor cell clones with different ER $\alpha$ and/or PgR expression within the same tumor lesion. Several preclinical studies have investigated this phenomenon; Graham M. et al. validated a new flow cytometry-based immunoassay and associated software for the simultaneous quantification of $\mathrm{PgR}$ levels and DNA indices of ploidy and cell cycle stages in any subset of the total cell population using the human BC cell line T47D and its clonal derivatives, and demonstrated a remarkable heterogeneity in PgR expression, thus confirming the existence of distinct tumor cell subclones that show a mixed response to antiestrogen treatment with tamoxifen [82]. More recently, a new method for ER mature transcript quantification in single cells has been validated in a study by Annaratone L. et al., consisting in a single-molecule RNA fluorescent in Situ Hybridization (FISH) in formalin-fixed, paraffin-embedded tissue sections (FFPE-smFISH), which allows for the quantification and spatial localization of the heterogeneous intratumor ER $\alpha$ 
expression, thus revealing that its spatial distribution can vary substantially even in the same tumor lesion [83].

Remarkably, the presence of intratumor heterogeneity of ER $\alpha$ expression has been associated with an increased risk of patient death [84]. This may depend on the fact that heterogeneous tumors are characterized by a higher number of biologically heterogeneous tumor clones with an augmented capacity to adapt to unfavorable growth conditions, including the selective pressure of anticancer treatments [84]. In the work by Davis B.W. et al., multiple intratumor tissue samples from 32 BC patients were analyzed, and in 4 out of 32 patients (12.5\%), both HR+ and HR- tumor areas were detected in the same lesion [85]. In the work of Chung G.G. et al., a hybrid IHC and flow cytometry technique employing fluorophores was used to analyze ER $\alpha$ expression in multiple tumor blocks/slides from primary BCs; notably, this study revealed a remarkable block-to-block heterogeneity in as much as $81 \%$ of cases [86]. Although the technique used in this study may have resulted in an over-estimation of the presence of intratumor heterogeneity, nevertheless, these results indicate that intratumor heterogeneity in the ER $\alpha$ expression is much more common than actually acknowledged. In a large series of 1085 invasive BC tissues, discordant biomarker status by tissue microarray was found in $9 \%$ and $16 \%$ of the analyzed samples for $\mathrm{ER} \alpha$ and $\mathrm{PgR}$, respectively, consistent with the existence of HR spatial heterogeneity [87].

Circulating tumor cells (CTCs), which detach from the primary tumor and move into the blood to establish metastatic seeds in distant organs, are detected in $10-67 \%$ of patients with any-stage BC, and are useful blood-based markers to predict clinical outcomes and to follow response to therapies [88]. Interestingly, as CTCs have similar chances to detach from different disease sites, they could potentially recapitulate intratumor heterogeneity. In the work of Babayan A. et al., among 35 patients with metastatic BC and ER $\alpha+$ primary tumors, CTCs were detected and immunostained in 16/35 patients $(46 \%)$. Notably, in only $31 \%$ of these cases did the CTCs show a homogeneous ER $\alpha$ expression, while in $50 \%$ of patients both ER $\alpha+$ and ER $\alpha-$ CTCs were detected; finally, $19 \%$ of cases only showed ER $\alpha-$ CTCs [89].

\section{HR Loss in Specific Clinical Settings}

HR status is unstable during BC progression as a result of genetic and epigenetic mechanisms; pre-existing intratumor heterogeneity; and clonal cell selection under the pressure of antitumor therapies, including ETs and chemotherapy.

Importantly, the occurrence of a biological tumor switch from HR+ to HR- status is associated with important prognostic implications; in a retrospective analysis including 459 patients with available tissues from both primary $\mathrm{BC}$ and local/distant $\mathrm{BC}$ recurrences, patients with neoplasms undergoing a conversion from $\mathrm{ER} \alpha+$ to $\mathrm{ER} \alpha$ - status had a $48 \%$ increase in the risk of death when compared with BC patients with stably ER $\alpha+$ status (hazard ratio, 1.48; 95\% CI, 1.08 to 2.05) [90].A loss of PgR expression in tumors that retain a high ER $\alpha$ expression has also been associated with more aggressive clinical behavior [33]. In particular, PgR loss promotes BC cell resistance to SERMs, but not to therapies that act by reducing blood estrogen concentration, such as aromatase inhibitors, or drugs that bind ER $\alpha$ and stimulate its degradation, such as SERDs [33]. It is unclear whether these data simply reflect a lower availability of effective therapies for $\mathrm{ER} \alpha-\mathrm{BC}$ when compared to $\mathrm{ER} \alpha+\mathrm{BC}$, or if they reflect the fact that cancer cells able to modify their epigenetic programs tend to display higher clinical aggressiveness.

In patients with early-stage BC treated with upfront surgery, the discordance rate in HR status between core needle biopsies (CNB) and paired surgical samples was reported to be low overall, i.e., $1.8 \%$ for ER $\alpha$ and $15 \%$ for PgR [91]. Similarly, discordances in ER $\alpha$ status between primary tumors and synchronous axillary lymph node metastases were found to be rare in a small patient cohort (2/50, $4 \%$ ) [92]. These data indicate that HR status evolution does not occur in the short-time interval before surgery (i.e., in patients not treated with neoadjuvant therapies), and that intratumor heterogeneity, which is likely to explain most of the observed discrepancies between diagnostic tumor biopsies and surgical specimens, is an overall uncommon finding in early-stage BC lesions [91,93]. 
When investigating HR status conversion, some technical aspects regarding the methodology of HR assessment should be taken into account. Indeed, ER $\alpha$ and PgR status is assessed by means of IHC, which evaluates the proportion of tumor cells expressing $\mathrm{ER} \alpha$ or $\mathrm{PgR}$, and which dichotomizes BC cells as HR+ or HR- based on a cut-off point of $1 \%$ for both proteins [94]. Firstly, different sampling methods (fine needle aspiration vs. CNB vs. surgical resection of the whole tumor lesion) may contribute to discrepant results for the IHC assessment of HRs; in particular, higher levels of HR expression are found in CNB-samples when compared with surgical specimens, which, more commonly undergo delays in tumor fixation that may result in degradation of the thermolabile ER $\alpha$ or PgR and, consequently, in lower IHC staining of these proteins [95]. Secondly, the HR status definition is affected by the reproducibility of the IHC staining techniques [96]. However, the standardization of validated IHC techniques for HR assessment in recent years, along with the reduction of non-validated assays, has greatly improved the quality and reproducibility of ER $\alpha$ and $\operatorname{PgR}$ testing [94]. Particular challenges for test reproducibility are represented by BC specimens with a low ER $\alpha$ and/or low PgR expression (1-10\%), whose assessment could be affected by both pre-analytic (e.g., fixation type and time) and analytic factors (e.g., antibody used), as well as by the tumor heterogeneity of the HR expression [94]. Finally, it should be highlighted that bone is the most frequent site of $\mathrm{BC}$ recurrences, and it has been reported that the decalcification process of biopsy samples, which is mandatory for IHC assessment in bone CNB specimens, may potentially alter the HR expression in BC [97].

The following paragraphs aim at discussing the clinical contexts in which HR loss has been reported in patients with BC.

\subsection{HR Loss after Neoadjuvant Treatments}

NAC is commonly used in BC patients with clinical stage II-III BC, for the purposes of (1) testing tumor sensitivity to systemic anticancer agents; (2) reducing tumor volume and, eventually, achieving pathologic complete response (pCR), which is associated with better long-term clinical outcomes; and (3) increasing the chance of performing conservative surgery. In recent years, NAC has become the standard-of-care treatment for patients with stage II-III TNBC, HER2+ BC, and luminal B-like BC, which are characterized by higher growth rates and more aggressive clinical behavior.

Some published studies indicate that HR status can be significantly modulated by neoadjuvant treatments [98-100]. Whether these changes are the result of the chemotherapy-induced selection of pre-existing tumor cell clones, or of chemotherapy-induced epigenetic modifications leading to changes in the ER $\alpha / \operatorname{PgR}$ expression, remains unclear. Independently of the molecular origin, NAC-induced loss of HR expression can have clinically relevant consequences; indeed, while the assessment of HR and HER2 status in CNBs is essential to guide the choice of preoperative treatments, biological tumor re-characterization after systemic neoadjuvant treatment in those patients failing to achieve pCR is essential for guiding post-surgical treatment planning. For instance, post-neoadjuvant T-DM1 has recently demonstrated improved DFS and OS in HER2+ BC patients failing to achieve PCR during pre-operative trastuzumab-based biochemotherapy [101], while post-neoadjuvant capecitabine has proven to be effective in increasing DFS and OS in TNBC patients failing to achieve tumor $\mathrm{pCR}$ after neoadjuvant therapy [102]. Based on these studies, assessment of the HR and HER2 status in tumor specimens after NAC is crucial for the definition of the subsequent therapeutic strategies, and therapeutic indications might change when modifications in HR or HER2 status are detected in surgical specimens when compared with diagnostic CNBs.

Several large studies have compared the ER $\alpha / \operatorname{PgR}$ expressions in primary tumors before and after NAC, with conflicting results, as illustrated below (Table 1). In an attempt to summarize these data, Van de Ven S. et al. conducted a meta-analysis of 32 significant studies that investigated the changes in ER $\alpha, \operatorname{PgR}$, and HER2 status in post- vs. pre-surgical BC samples in patients that received NAC or neoadjuvant trastuzumab-based biochemotherapy [103]. Studies employing neoadjuvant endocrine therapy were excluded from the meta-analysis. Overall, discordances in the HR status between the first CNB and post-NAC tumor specimens were reported in $8-33 \%$ of patients. In general, larger 
studies reported higher rates of HR status conversion, and also showed a more marked discordance in PgR status (discordance rates for ER $\alpha$ and PgR status were 2.5-17\% and 5.9-51.7\%, respectively). Interestingly, the meta-analysis revealed a correlation between the changes in HR and HER2 status after NAC. In particular, most tumors displaying an increase in ER $\alpha$ expression after neoadjuvant treatment also underwent a decrease in HER2 expression; similarly, loss of HER2 amplification was associated with an increased ER $\alpha$ expression after NAC plus trastuzumab-based treatment. Together, these data support the hypothesis that similar molecular pathways, or a common transcriptional instability, could sustain these biological switches.

When considering individual trials included in the meta-analysis, the results regarding HR conversion were quite discordant, thus indicating that the centers in which the study was conducted, or the differences in patient characteristics, patient number, technique of HR status assessment, tumor sampling, and concomitant therapies administered, might significantly affect the rate of HR status conversion.

In a retrospective study including 420 patients with operable BC and treated with different NAC schedules, Tacca O. et al. reported changes in HR status in $23 \%$ of patients, with HR- to HR+ status conversion being the most commonly reported event ( $42 \%$ of initially HR- patients) [104]. In this study, patients undergoing a biological switch from HR- to HR+ status had significantly better DFS and OS when compared with patients with stable HR- status after NAC, while no significant differences in clinical outcomes were observed between patients undergoing HR- to HR+ status conversion and patients with stable HR+ tumors. These results indicate that the biological status of the tumor at surgery can affect patient prognosis and the clinical benefit from adjuvant therapies.

However, in the study by Chen S. et al. [105], patients with HR+ to HR-conversion did not show a different clinical benefit from adjuvant ETs when compared with patients with a stable HR+ status, thus indicating that $\mathrm{HR}+\mathrm{BC}$ micrometastatic clones retain sensitivity to ETs in the vast majority of patients undergoing HR+ to HR- conversion. Loss of HR positivity was also associated with worse DFS and OS in the studies by Jin X. et al. [106] and Lim S.K. et al. [107]; finally, Ding Y. et al. found that a loss of $\mathrm{PgR}$ positivity was associated with worse OS [108].

Regarding the impact of neoadjuvant ETs on HR status, a few published studies indicate that preoperative tamoxifen or aromatase inhibitors could reduce the ER $\alpha$ and PgR expression, respectively $[109,110]$. The different effects of different ETs on the ER $\alpha$ and PgR expressions could result from the different mechanisms of action of these compounds. Indeed, while SERMs bind ER $\alpha$ and could promote its ubiquitination and degradation, aromatase inhibitors reduce ER $\alpha$ binding to its agonists, thus inhibiting ER $\alpha$-mediated signaling without affecting ER $\alpha$ levels. In the outdated study by Hawkins R.A. et al., neoadjuvant tamoxifen caused a marked reduction in ER $\alpha$ expression, in contrast to most other forms of systemic therapy that only resulted in minor changes in Er $\alpha$ levels [111]. In the study by Miller W.R. et al., neoadjuvant tamoxifen caused a reduction in ER $\alpha$ expression along with an increase in PgR (likely as a consequence of estrogen agonistic activity of tamoxifen); on the other hand, letrozole had minor effects on ER $\alpha$ expression, but it was associated with a dramatic reduction of PgR levels, likely as a result of lower blood estrogen and lower ER $\alpha$ activation and signaling [112].

To the best of our knowledge, no studies evaluating HR conversion in the context of HR+ BC patients treated with neoadjuvant ET plus cyclin-dependent kinase (CDK) $4 / 6$ inhibitors have been published yet.

Taken together, the available clinical evidence shows that HR conversion is a common finding in BC patients receiving NAC. Based on these data, HR status should be always re-assessed in surgical tumor specimens after NAC in order to select the most appropriate post-NAC systemic treatment. 
Table 1. Studies investigating the discordance rate between core needle biopsies (CNB)and synchronous LN (lymph nodes)/surgical specimens.

\begin{tabular}{|c|c|c|c|c|c|c|}
\hline Author & Methods & Site & $\begin{array}{l}\text { Previous } \\
\text { Treatments }\end{array}$ & $\mathrm{ER} \alpha(\%)$ & $\operatorname{PgR}(\%)$ & $\begin{array}{l}\text { HR Status } \\
\quad(\%)\end{array}$ \\
\hline $\begin{array}{l}\text { Hawkins R.A. et al. } \\
\quad(1990) \text { [111] }\end{array}$ & $\begin{array}{l}\text { Prospective } \\
\mathrm{N}=62 \mathrm{pts}\end{array}$ & $\begin{array}{l}\text { Surgical } \\
\text { sample }\end{array}$ & Various & n.s & - & - \\
\hline $\begin{array}{l}\text { Miller W.R. et al. } \\
\text { (2003) [112] }\end{array}$ & $\begin{array}{l}\text { Retrospective } \\
\mathrm{N}=48 \text { pts }\end{array}$ & $\begin{array}{l}\text { Surgical } \\
\text { sample }\end{array}$ & $\begin{array}{l}\text { Letrozole } \\
\text { vs } \\
\text { tamoxifen }\end{array}$ & $\begin{array}{l}48 \\
\text { vs } \\
83\end{array}$ & $\begin{array}{l}87 \\
\text { vs } \\
60\end{array}$ & - \\
\hline $\begin{array}{l}\text { Tacca O. et al. } \\
\text { (2007) [104] }\end{array}$ & $\begin{array}{l}\text { Retrospective } \\
\mathrm{N}=459 \mathrm{pts}\end{array}$ & $\begin{array}{l}\text { Surgical } \\
\text { sample }\end{array}$ & Various & - & - & 23 \\
\hline $\begin{array}{l}\text { Hirata T. et al. } \\
\text { (2009) [99] }\end{array}$ & $\begin{array}{l}\text { Retrospective } \\
\mathrm{N}=368 \mathrm{pts}\end{array}$ & $\begin{array}{l}\text { Surgical } \\
\text { sample }\end{array}$ & Various & 14.9 & 29.1 & 16 \\
\hline $\begin{array}{l}\text { Aitken S.J.et al. } \\
\text { (2010) [93] }\end{array}$ & $\begin{array}{c}\text { Retrospective } \\
\mathrm{N}=385 \mathrm{pts}\end{array}$ & $\begin{array}{l}\text { Synchronous } \\
\text { LN }\end{array}$ & None & 28.3 & 23.4 & - \\
\hline $\begin{array}{l}\text { Van de VenS. et al. } \\
\quad \text { (2011) [103] }\end{array}$ & $\begin{array}{c}\text { Metanalysis } \\
\mathrm{N}=32 \text { studies }\end{array}$ & $\begin{array}{l}\text { Surgical } \\
\text { sample }\end{array}$ & Various & $2.5-17$ & 5.9-19 & $8-33$ \\
\hline $\begin{array}{c}\text { Jensen J.D. et al. } \\
\text { (2012) [92] }\end{array}$ & $\begin{array}{l}\text { Prospective } \\
\mathrm{N}=128 \text { pts }\end{array}$ & $\begin{array}{c}\text { Synchronous } \\
\text { LN }\end{array}$ & None & 4 & - & - \\
\hline $\begin{array}{l}\text { Chen S. et al. } \\
(2012) \text { [105] }\end{array}$ & $\begin{array}{l}\text { Retrospective } \\
\mathrm{N}=224 \text { pts }\end{array}$ & $\begin{array}{l}\text { Surgical } \\
\text { sample }\end{array}$ & $\begin{array}{c}\text { CEF }(29.0 \%), \\
\text { NE }(35.7 \%), \\
\text { PC }(29.9 \%) \text {, or } \\
\text { TE }(5.4 \%)^{1}\end{array}$ & $\begin{array}{c}16 \\
(+ \text { to }-)\end{array}$ & $\begin{array}{c}22.2 \\
(+ \text { to }-)\end{array}$ & $\begin{array}{c}15.2 \\
(+ \text { to }-)\end{array}$ \\
\hline $\begin{array}{l}\text { Jin X. et al. } \\
\text { (2015) [106] }\end{array}$ & $\begin{array}{l}\text { Prospective } \\
N=423 \text { pts }\end{array}$ & $\begin{array}{l}\text { Surgical } \\
\text { sample }\end{array}$ & Various & - & - & 18.4 \\
\hline $\begin{array}{l}\text { Lim S.K. et al. } \\
\text { (2016) [107] }\end{array}$ & $\begin{array}{l}\text { Retrospective } \\
\mathrm{N}=322 \mathrm{pts}\end{array}$ & $\begin{array}{l}\text { Surgical } \\
\text { sample }\end{array}$ & Various & 40.7 & 62.1 & 17.9 \\
\hline $\begin{array}{l}\text { Ding Y. et al. } \\
\text { (2020) [108] }\end{array}$ & $\begin{array}{l}\text { Retrospective } \\
\mathrm{N}=482 \text { pts }\end{array}$ & $\begin{array}{l}\text { Surgical } \\
\text { sample }\end{array}$ & $\begin{array}{l}\text { Anthracyclines } \\
\text { and/or taxanes }\end{array}$ & 10.4 & 17 & 27.4 \\
\hline
\end{tabular}

${ }^{1}$ CEF: cyclofosphamide + epirubicin + 5-fluorouracil; NE: navelbine + epirubicin; PC: paclitaxel + carboplatin; TE: docetaxel + epirubicin.

\subsection{HR Loss in Recurrent/Metastatic BC}

In spite of continuous progresses in the treatment of early-stage BC during the last decades, BC recurrence, in the form of local or distant relapses, occurs in approximately $15-20 \%$ of patients with surgically-resected HR+/HER2- BC $[113,114]$. Therefore, recurrent BC remains an unmet clinical issue, and the vast majority of patients with metastatic $\mathrm{BC}$ still die of their disease.

In a retrospective study by Simmons C. et al., 20\% of patients with metastatic BC underwent a change in their treatment plan based on the results of the biopsy of one metastatic lesion, and in particular, on the basis of HR and HER2 status re-assessment [115]. Therefore, the treatment of recurrent and metastatic BC should be guided by biological re-characterization of the tumor, which should include a re-assessment of the HR and HER2 status. Although current clinical guidelines recommend biological re-characterization of tumor recurrences as frequently as possible, the optimal frequency of HR re-assessment (i.e., after every change of systemic treatment vs. after the diagnosis of the first local/distant recurrence) remains unclear.

Changes in HR status between the primary tumor and metastatic lesions have prognostic value, with the conversion from HR+ BC to TNBC being associated with the worst clinical outcome [10]. Conversely, the acquisition of the HR expression in previously HR- BC is associated with better clinical outcomes, partly as a result of a higher number of available treatment options for patients with $\mathrm{HR}+\mathrm{BC}$.

The meta-analysis by Aurilio G. et al., which included 48studies, aimed at comparing HR status in primary $\mathrm{BCs}$ and in matched $\mathrm{BC}$ recurrences [15]. The biological features of primary BCs were 
reassessed at relapse to estimate the rates of ER $\alpha$ and/or PgR status conversion. Studies included in this meta-analysis were heterogeneous in terms of the treatments administered and the number of patients included. ER $\alpha$ status was assessed in 33 studies; with a total number of 4200 patients analyzed, the overall rate of ER $\alpha$ status conversion in primary vs. recurrent tumor specimens was $20 \%$ (95\% CI: 16-35\%); in particular, HR conversion from ER $\alpha$-positive (ER $\alpha+)$ to ER $\alpha$-negative (ER $\alpha-$ ) status occurred in approximately $24 \%$ of patients (95\% CI: 9-20\%), while ER $\alpha-$ to ER $\alpha+$ conversion occurred in 14\% of patients (95\% CI: 9-20\%). PgR status conversion was assessed in 24 studies, with a total of 2739 patients analyzed, $\mathrm{PgR}$ status conversion was reported in approximately $33 \%$ of cases (95\% CI: 28-37\%). The pooled rates of PgR-positive (PgR+) to PgR-negative (PgR-) and PgR- to PgR+ conversion were $46 \%$ (95\% CI: 37-55\%) and 15\% (95\% CI: $12-17 \%)$, respectively $(p<0.0001)$. Interestingly, stratified analyses according to the site of the tumor relapse revealed similar pooled ER $\alpha$ discordance proportions in the case of loco-regional and metastatic recurrences, while discordance proportions for PgR expression were lower in loco-regional tumor recurrences (26\%; 95\% CI: $21-32 \%$ ) than in distant metastases (41\%; 95\% CI: 37-45\%). Notably, studies included in the meta-analysis showed discordant survival outcomes associated with HR conversion; for instance, while, in the study by Amir E. et al., patients undergoing HR status conversion did not have worse OS, in the study by Dieci M.V.et al., HR+ to HR- conversion was associated with significantly lower post-relapse OS [116,117]. Based on the results of this meta-analysis, the authors highlighted the importance of re-assessing the tumor biology, especially in the following clinical contexts: (1) BC recurrences occurring along time after primary BC diagnosis (which indicates the evolution of tumor cell clones that remained quiescent for a long time, and which probably underwent progressive clonal selection during/after adjuvant therapies), (2) disease progression in the context of early and frequent treatment failures (which suggest the presence of highly dynamic tumor cell clones that could have been rapidly selected during previous therapies), and (3) conditions where the detection of a specific biological alteration could guide clinicians in the choice of molecular targeted therapies. Whether HR conversion from primary $\mathrm{BC}$ to recurrent/metastatic $\mathrm{BC}$ occurs more frequently after the administration of post-surgical systemic treatments has been poorly investigated (Table 2).

In the retrospective study by Kuukasjärvi T. et al., which included 50 patients not receiving any adjuvant treatment, the discordance rate in HR status between primary BC samples and matched metachronous $\mathrm{BC}$ recurrences was $36 \%$; in this study, all conversion events consisted in the loss of $\mathrm{ER} \alpha$ and/or $\operatorname{PgR}$ expression, while no $\mathrm{ER} \alpha-$ to $\mathrm{ER} \alpha+$ or $\operatorname{PgR}-$ to $\operatorname{PgR}+$ conversions were detected [81]. In this study, a loss of Er $\alpha$ expression in recurrent $B C$ was associated with a poor clinical benefit from ETs, with only $12.5 \%$ of patients with $E R \alpha$ - tumors responding to tamoxifen-based therapy (compared with $74 \%$ of patients retaining intratumor Er $\alpha$ expression). Lower E.E. et al. retrospectively compared HR expression in matched primary and metastatic BC specimens from 200 patients, 167 of whom received adjuvant treatments, which consisted of adjuvant chemotherapy alone in 102 patients, or of tamoxifen, alone or with other therapies, in 65 patients [118]. The authors found a discordance rate of $30 \%$ regarding ER $\alpha$ status, with a switch from $E R \alpha+$ to $E R \alpha-$ status in $19.5 \%$ of patients. The discordance rate was $39.3 \%$ for the PgR expression. In this study, adjuvant tamoxifen was not specifically associated with increased ER $\alpha$ discordance rates; indeed, ER $\alpha$ expression was lost in 34\% of patients who were treated with tamoxifen and in $38 \%$ of patients who were not. Of note, patients with tumors retaining the ER $\alpha$ expression at the time of recurrence had a significantly longer OS when compared with patients with tumors losing ER $\alpha$ expression; conversely, discordance in the PgR expression was not associated with patient OS.

In the study by Stueber T. et al., which included196 patients, the observed rate of ER $\alpha+$ to $\mathrm{ER} \alpha-$ conversion was $33.3 \%$, while the PgR+ to PgR- conversion rate was 59.6\% [119]. Notably, both tamoxifen and chemotherapy, when administered in the adjuvant setting, were associated with a significantly lower risk of undergoing disease recurrence as $E R \alpha-B C$, thus indicating that in some contexts, $\mathrm{ER} \alpha-/ \mathrm{PgR}$ - clones might originate from $\mathrm{HR}+\mathrm{BC}$ clones that undergo modifications in their epigenetic programs, rather than from the selection of initially $\mathrm{ER} \alpha-/ \mathrm{PgR}-$ tumor clones. If this 
hypothesis is correct, adjuvant ETs could help prevent the formation of ER $\alpha$ - cell clones, rather than selecting them. In this paper, the authors also reported a higher risk of HR conversion at relapse in women who underwent axillary lymph node dissection because of initial lymph node tumor involvement, with a trend towards a higher conversion risk in the case of low-grade primary tumors. Conversely, no significant correlation between menopausal status or familial predisposition and any receptor change was found.

In contrast with previously discussed works [118-120], in the study by Lindström L.S. et al., ER $\alpha$ expression loss at recurrence was more common among patients who received ET alone (29\%) or chemotherapy followed by ET $(34.3 \%)$ in the adjuvant setting, while it was less frequent in patients treated with chemotherapy alone $(19.8 \%)$ and in patients who did not receive any adjuvant therapy $(11.5 \%)$ [90]. In contrast with the study by Stueber T., this study indicates that ETs could favor the formation HR- tumor clones, or simply select the growth and proliferation of pre-existing HR- subclones.

With regards to specific (neo)adjuvant treatment agents, in the study by Ongaro E. et al. [120], previous exposure to anthracyclines or taxanes was associated with a loss of PgR expression (OR 6.5) or with its quantitative reduction (OR 5.3). Conversely, previous exposure to taxanes or aromatase inhibitors was associated with a quantitative reduction of Er $\alpha$ expression in BC recurrences (OR of 3.6 and 2.5, respectively). As for the different metastatic sites, in the meta-analysis conducted by Schrijver W.A.M.E. et al. [16], the authors analyzed location-specific discordance in HR status among different studies, and found that the ER $\alpha$ expression status was more frequently discordant in the central nervous system (20.8\%) and in bone metastases (29.3\%) when compared with liver metastases $(14.3 \%)$. On the other hand, the PgR status was more commonly discordant in the bone $(42.7 \%)$ and liver metastases (47\%) when compared with the CNS metastases (23.3\%).

As in the context of neoadjuvant therapies, data on HR conversion in patients treated with ET plus CDK4/6 inhibitors in the setting of advanced disease are still lacking.

Table 2. Previous studies investigating the discordance rate between primary tumor and local recurrence/distant metastases.

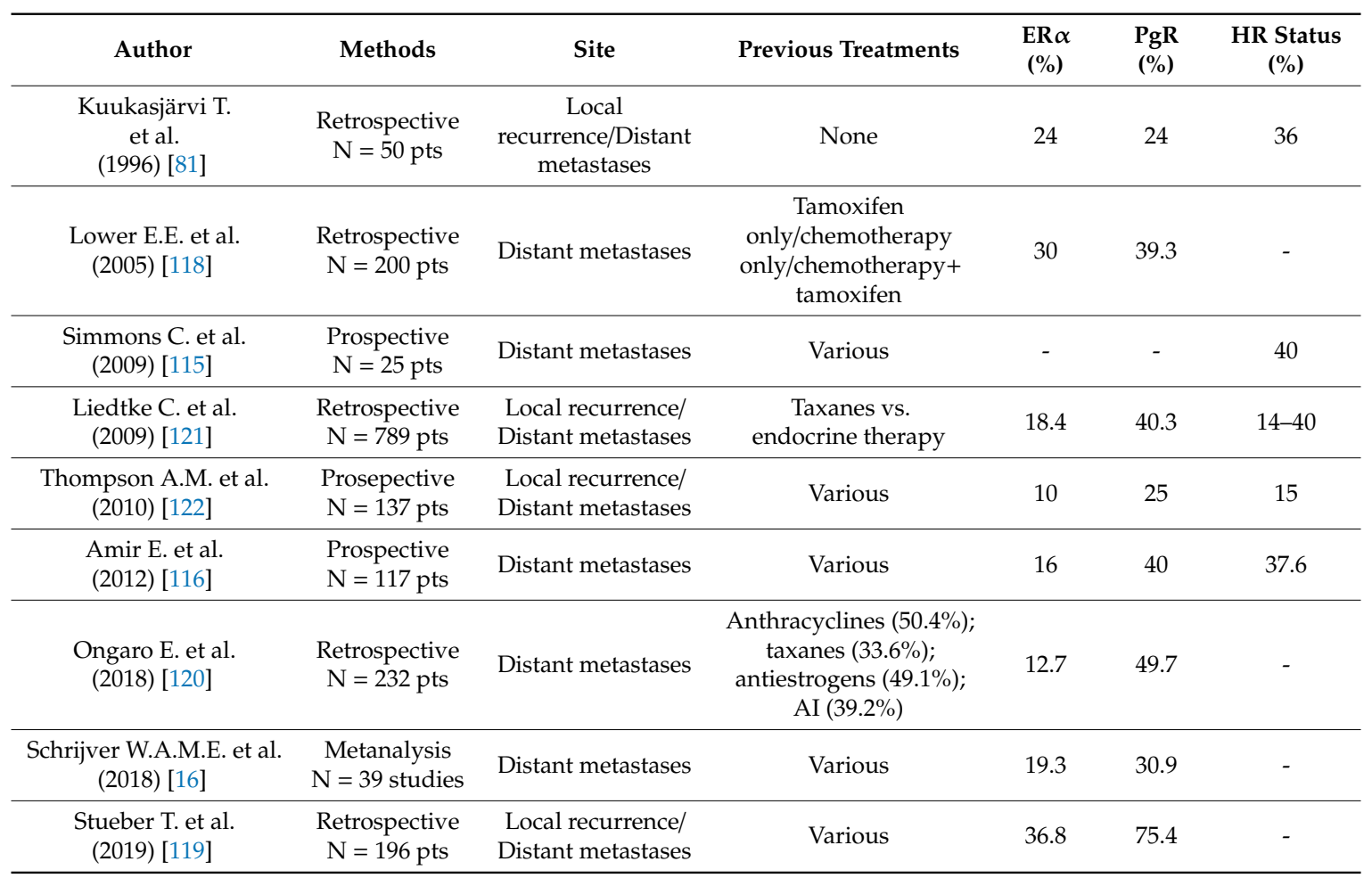




\section{Therapeutic Implications}

As HR status conversion is a common phenomenon in BC patients treated with different types of antineoplastic therapies, and residual tumor tissues after NAC, local or distant BC recurrences after the resection of the primary tumor, and tumor sites undergoing progression during subsequent lines of therapy for advanced disease should be biologically re-assessed whenever possible so as to re-evaluate HR status. In this clinical context, the re-characterization of both HR and HER2 status is crucial in order to guide the choice of subsequent lines of therapy.

In post-NAC tumor residues, changes in HR and/or HER2 status could significantly modify therapeutic decisions regarding post-neoadjuvant therapies. For instance, patients with TNBC undergoing conversion towards $\mathrm{HR}+\mathrm{BC}$ could benefit from adding ETs to adjuvant capecitabine, while tumor conversion from $\mathrm{HR}+\mathrm{BC}$ to TNBC after NAC might suggest an advantage from adding capecitabine to adjuvant ETs. Similarly, tumor conversion from HER2+/HR- BC to HER2+/HR+ BC suggests the opportunity to combine ETs with post-neoadjuvant T-DM1 or trastuzumab, while tumor conversion from HER2-/HR+ BC to HER2+/HR+ BC indicates the potential utility of adding T-DM1 to adjuvant ETs. As a general principle, combination therapies targeting both $\mathrm{HR}+$ and $\mathrm{HR}-\mathrm{BC}$ cell clones in patients with tumors undergoing HR status conversions should be preferred whenever possible. Indeed, HR status conversion suggests the potential presence of both HR+ and HR- BC cell clones that could be responsible for the long-term formation of distant metastatic lesions.

In the case of distant BC recurrences after (neo)adjuvant therapies or surgery for limited-stage BC, clinical guidelines aimed at biological tumor re-characterization indicate soft tissue $\mathrm{BC}$ biopsies as a preferred option when compared with biopsies of bone metastases, because the former allow for more accurate biomarker assessment and preserve tumor specimens from alterations resulting from the use of harsh decalcification solutions [11]. Whenever the occurrence of HR status conversion in $\mathrm{BC}$ recurrences is confirmed, therapeutic decisions should be customized on a case-by-case basis, i.e., depending on the burden of the disease, the number and type of previous lines of therapy received, tumor response to these therapies, and the duration of the response. At the extreme of the clinical spectrum, if tumor relapse after curative surgery occurs in a single distant site and ER $\alpha-$ to ER $\alpha+$ conversion is detected, first-line ET plus/minus CDK 4/6 inhibitors should be the preferred treatment option. Conversely, if the patient presents with multiple metastatic sites from a previous $\mathrm{ER} \alpha-\mathrm{BC}$, and there is proven ER $\alpha$ positivity in one biopsied site, ET plus CDK 4/6 inhibitor combination could be proposed as a first-line therapeutic option (with the exception of ongoing or pending visceral crisis), but then it should be replaced by cytotoxic chemotherapy or other treatment options if one or more metastatic sites undergo progression at disease re-evaluation. In contrast, in the case of ER $\alpha+$ to $\mathrm{ER} \alpha-$ conversion, treatment choices should be guided by the clinical course of the disease. In the presence of one single metastatic lesion or oligometastatic disease, cytotoxic chemotherapy could be the preferred treatment option. In the case of multiple metastatic sites, combining chemotherapy with ETs could increase the chances of successfully targeting biologically heterogeneous (ER $\alpha+$ and ER $\alpha-$ ) tumor lesions.

In the future, new methods capable of reliably detecting the heterogeneity of HR status in different metastatic tumor lesions could revolutionize the therapeutic algorithm in patients undergoing HR- to $\mathrm{HR}+$ or HR+ to HR- tumor conversions. In a recent study by Paolillo C. et al., which was conducted in patients with advanced $\mathrm{HR}+\mathrm{BC}$ treated with ET, ER $\alpha$ expression in CTCs revealed a remarkable heterogeneity across different cells. In particular, most samples in which CTCs were detected showed a biologically mixed population of $\mathrm{ER} \alpha+$ and $\mathrm{ER} \alpha-\mathrm{BC}$ cells, and in five patients, all CTCs were negative for ER $\alpha$ expression [123]. While the assessment of HR status in CTCs is a promising approach that could allow for the detection of HR heterogeneity in BC patients, a relationship between ER $\alpha$ expression in CTCs and the presence of specific metastatic sites have not been elucidated yet. In particular, it is still unclear if CTCs equally represent biologically heterogeneous metastatic lesions, or, alternatively, if they represent the most biologically and clinically aggressive tumor clones (e.g., those lacking ER $\alpha$ expression). 
Another innovative approach consists of the development and improvement of imaging techniques capable of providing in vivo visualization of ER $\alpha$ expression in individual tumor lesions. Among these methods, 16a-[18F]-fluoro-17b-estradiol (FES) PET/CT is capable of accurately localizing tumor lesions expressing ER $\alpha$, and also of predicting ET sensitivity in patients with advanced HR+ BC [124]. Of note, FES PET/CT scans performed before the initiation of ETs in patients with advanced $\mathrm{ER} \alpha+\mathrm{BC}$ revealed heterogeneous FES avidity across different individuals $[125,126]$. In the study by Linden $\mathrm{H}$. et al., the lack of FES uptake was reported in at least one metastatic site in $10 \%$ of patients with primary ER $\alpha+B C$, reflecting the presence of different tumor clones [127]. Conversely, the reduction in FES avidity during ETs may be due to receptor occupancy and/or loss. Repeating FES PET/CT scans during ET course could indeed guide treatment choices.

While new diagnostic approaches could increase our ability to visualize HR status heterogeneity in $\mathrm{HR}+\mathrm{BC}$ and, consequently, to guide treatment choices in a personalized way, prospective studies are needed in order to investigate whether tailoring pharmacological treatments in HR+ BC patients on the basis of intratumor heterogeneity of HR expression is capable of improving clinical outcomes when compared with the currently available clinical guidelines.

\section{Conclusions}

$\mathrm{HR}+$ to $\mathrm{HR}$ - conversion is a common biological phenomenon in BC patients, especially after neoadjuvant therapies (i.e., in residual tumor cells) and in the case of $\mathrm{BC}$ recurrences after surgery. Regardless of the underlying molecular mechanisms, which include treatment-driven genetic/epigenetic alterations affecting ESR1/PGR transcription, ESR1/PGR translation, or ER $\alpha / \operatorname{PgR}$ activity, as well as intratumor HR status heterogeneity, this phenomenon can severely impact treatment choices and the efficacy of antitumor therapies. Therefore, performing tumor re-biopsy to achieve HR status re-characterization of $\mathrm{BC}$ recurrences or progressing lesions should be recommended whenever feasible in order to tailor treatment on the basis of HR status. At the same time, as different tumor lesions can display different HR expressions, new methods allowing for the visualization of heterogeneous tumor lesions, such as HR characterization in CTCs or FES PET/CT scans, could help clinicians choose the most effective treatment in specific clinical contexts.

Author Contributions: Conceptualization, C.V.; methodology, E.Z., R.L. (Rita Leporati) and C.V.; software, E.Z., R.L. (Rita Leporati) and C.V.; formal analysis, E.Z., R.L. (Rita Leporati) and C.V.; investigation, E.Z., R.L. (Rita Leporati), G.P. and C.V.; data curation, E.Z., R.L. (Rita Leporati), F.L., R.L. (Riccardo Lobefaro), A.V., G.P., C.V.; writing - original draft preparation, E.Z., R.L. (Rita Leporati), G.P., C.V.; writing—review and editing, E.Z., R.L. (Rita Leporati) and C.V.; supervision, G.P. and C.V.; project administration, G.P. and C.V. All authors have read and agreed to the published version of the manuscript.

Funding: This research received no external funding.

Acknowledgments: We would like to thank the Associazione Italiana per la Ricerca sul Cancro (AIRC; MFAG-2019 n. 22977: PI Claudio Vernieri) and the Scientific Directorate of Fondazione IRCCS Istituto Nazionale dei Tumori (Milan, Italy) for funding our research.

Conflicts of Interest: The authors declare no conflict of interest.

\section{References}

1. Perou, C.M.; Sørile, T.; Eisen, M.B.; Van De Rijn, M.; Jeffrey, S.S.; Ress, C.A.; Pollack, J.R.; Ross, D.T.; Johnsen, H.; Akslen, L.A.; et al. Molecular portraits of human breast tumours. Nature 2000, 406, 747-752. [CrossRef] [PubMed]

2. Grimm, S.L.; Hartig, S.M.; Edwards, D.P. Progesterone Receptor Signaling Mechanisms. J. Mol. Biol. 2016, 428, 3831-3849. [CrossRef] [PubMed]

3. Levin, E.R. Integration of the extranuclear and nuclear actions of estrogen. Mol. Endocrinol. 2005, 19, 1951-1959. [CrossRef] [PubMed]

4. $\quad$ Lindberg, M.K.; Rare, S.M.; Skrtic, S.; Gao, H.; Dahlman-Wright, K.; Gustafsson, J.-Å.; Ohlsson, C. Estrogen Receptor (ER)-Reduces ER-Regulated Gene Transcription, Supporting a "Ying Yang" Relationship between ER and ER in Mice. Mol. Endocrinol. 2003, 17, 203-208. [CrossRef] 
5. Paruthiyil, S.; Parmar, H.; Kerekatte, V.; Cunha, G.R.; Firestone, G.L.; Leitmant, D.C. Estrogen Receptor $\beta$ Inhibits Human Breast Cancer Cell Proliferation and Tumor Formation by Causing a G2 Cell Cycle Arrest. Cancer Res. 2004, 64, 423-428. [CrossRef]

6. Chang, E.C.; Frasor, J.; Komm, B.; Katzenellenbogen, B.S. Impact of Estrogen Receptor on Gene Networks Regulated by Estrogen Receptor in Breast Cancer Cells. Endocrinology 2006, 147, 4831-4832. [CrossRef]

7. Gruvberger-Saal, S.K.; Bendahl, P.O.; Saal, L.H.; Laakso, M.; Hegardt, C.; Edén, P.; Peterson, C.; Malmström, P.; Isola, J.; Borg, A.; et al. Estrogen receptor $\beta$ expression is associated with tamoxifen response in ER $\alpha$-negative breast carcinoma. Clin. Cancer Res. 2007, 13, 1987-1994. [CrossRef]

8. Onitilo, A.A.; Engel, J.M.; Greenlee, R.T.; Mukesh, B.N. Breast Cancer Subtypes Based on ER/PR and Her2 Expression: Comparison of Clinicopathologic Features and Survival. Clin. Med. Res. 2009, 7, 4-13. [CrossRef]

9. Cortazar, P.; Zhang, L.; Untch, M.; Mehta, K.; Costantino, J.P.; Wolmark, N.; Bonnefoi, H.; Cameron, D.; Gianni, L.; Valagussa, P.; et al. Pathological complete response and long-term clinical benefit in breast cancer: The CTNeoBC pooled analysis. Lancet 2014, 384, 164-172. [CrossRef]

10. Liedtke, C.; Mazouni, C.; Hess, K.R.; André, F.; Tordai, A.; Mejia, J.A.; Symmans, W.F.; Gonzalez-Angulo, A.M.; Hennessy, B.; Green, M.; et al. Response to neoadjuvant therapy and long-term survival in patients with triple-negative breast cancer. J. Clin. Oncol. 2008, 26, 1275-1281. [CrossRef]

11. Lurie, R.H.; Anderson, B.O.; Abraham, J.; Aft, R.; Agnese, D.; Allison, K.H.; Blair, S.L.; Burstein, H.J.; Dang, C.; Elias, A.D.; et al. NCCN Guidelines Version 6.2020 Breast Cancer; National Comprehensive Cancer Network: Plymouth Meeting, PA, USA, 2020.

12. Razavi, P.; Chang, M.T.; Xu, G.; Bandlamudi, C.; Ross, D.S.; Vasan, N.; Cai, Y.; Bielski, C.M.; Donoghue, M.T.A.; Jonsson, P.; et al. The Genomic Landscape of Endocrine-Resistant Advanced Breast Cancers. Cancer Cell 2018, 34, 427-438. [CrossRef] [PubMed]

13. Turner, N.C.; Swift, C.; Kilburn, L.; Fribbens, C.; Beaney, M.; Garcia-Murillas, I.; Budzar, A.U.; Robertson, J.F.R.; Gradishar, W.; Piccart, M.; et al. ESR1 Mutations and Overall Survival on Fulvestrant versus Exemestane in Advanced Hormone Receptor-Positive Breast Cancer: A Combined Analysis of the Phase III SoFEA and EFECT Trials. Clin. Cancer Res. 2020, 26, 5172-5177. [CrossRef] [PubMed]

14. Allred, D.C.; Mohsin, S.K.; Fuqua, S.A.W. Histological and biological evolution of human premalignant breast disease. Endocr. Relat Cancer 2001, 8, 47-61. [CrossRef] [PubMed]

15. Aurilio, G.; Disalvatore, D.; Pruneri, G.; Bagnardi, V.; Viale, G.; Curigliano, G.; Adamoli, L.; Munzone, E.; Sciandivasci, A.; De Vita, F.; et al. A meta-analysis of oestrogen receptor, progesterone receptor and human epidermal growth factor receptor 2 discordance between primary breast cancer and metastases. Eur. J. Cancer 2014, 50, 277-289. [CrossRef]

16. Schrijver, W.A.M.E.M.E.; Suijkerbuijk, K.P.M.M.; van Gils, C.H.; van der Wall, E.; Moelans, C.B.; van Diest, P.J. Receptor Conversion in Distant Breast Cancer Metastases: A Systematic Review and Meta-analysis. J. Natl. Cancer Inst. 2018, 110, 568-580. [CrossRef]

17. Rose, D.P. Effects of Adjuvant Chemohormonal Therapy on the Ovarian and Adrenal Function of Breast Cancer Patients. Cancer Res. 1980, 40, 4043-4047.

18. Galli, G.; Bregni, G.; Cavalieri, S.; Porcu, L.; Baili, P.; Hade, A.; Di Salvo, F.; Sant, M.; Agresti, R.; Gennaro, M.; et al. Neoadjuvant Chemotherapy Exerts Selection Pressure Towards Luminal Phenotype Breast Cancer. Breast Care 2017, 12, 391-394. [CrossRef]

19. Huang, W.; Peng, Y.; Kiselar, J.; Zhao, X.; Albaqami, A.; Mendez, D.; Chen, Y.; Chakravarthy, S.; Gupta, S.; Ralston, C.; et al. Multidomain architecture of estrogen receptor reveals interfacial cross-talk between its DNA-binding and ligand-binding domains. Nat. Commun. 2018, 9, 1-10. [CrossRef]

20. Press, M.F.; Nousek-Goebl, N.A.; Bur, M.; Greene, G.L. Estrogen receptor localization in the female genital tract. Am. J. Pathol. 1986, 123, 280-292. [CrossRef]

21. Press, M.F.; Xu, S.-H.; Wang, J.-D.; Greene, G.L. Subcellular distribution of estrogen receptor and progesterone receptor with and without specific ligand. Am. J. Pathol. 1989, 135, 857-864.

22. Tecalco-Cruz, A.C.; Pérez-Alvarado, I.A.; Ramírez-Jarquín, J.O.; Rocha-Zavaleta, L. Nucleo-cytoplasmic transport of estrogen receptor alpha in breast cancer cells. Cell. Signal. 2017, 34, 121-132. [CrossRef] [PubMed]

23. Wärnmark, A.; Treuter, E.; Wright, A.P.H.H.; Gustafsson, J.-A.Å.; Wärnmark, A.; Treuter, E.; Wright, A.P.H.H.; Gustafsson, J.-A.A. Activation Functions 1 and 2 of Nuclear Receptors: Molecular Strategies for Transcriptional Activation. Mol. Endocrinol. 2003, 17, 1901-1909. [CrossRef] [PubMed] 
24. Chen, D.; Riedl, T.; Washbrook, E.; Pace, P.E.; Coombes, R.C.; Egly, J.M.; Ali, S. Activation of estrogen receptor $\alpha$ by S118 phosphorylation involves a ligand-dependent interaction with TFIIH and participation of CDK7. Mol. Cell 2000, 6, 127-137. [CrossRef]

25. Pietras, R.J.; Márquez-Garbán, D.C. Membrane-associated estrogen receptor signaling pathways in human cancers. Clin. Cancer Res. 2007, 13, 4672-4676. [CrossRef] [PubMed]

26. Fan, P.; Wang, J.; Santen, R.J.; Yue, W. Long-term treatment with tamoxifen facilitates translocation of estrogen receptor $\alpha$ out of the nucleus and enhances its interaction with EGFR in MCF-7 breast cancer cells. Cancer Res. 2007, 67, 1352-1360. [CrossRef]

27. Jeselsohn, R.; Buchwalter, G.; De Angelis, C.; Brown, M.; Schiff, R. ESR1 mutations-a mechanism for acquired endocrine resistance in breast cancer. Nat. Rev. Clin. Oncol. 2015, 12, 573-583. [CrossRef]

28. Zheng, W.Q.; Zheng, J.M.; Lu, J.; Hu, F.X. Loss of heterozygosity of ER gene in breast cancer and its clinical significance. Chin. J. Cancer Res. 2002, 14, 122-125. [CrossRef]

29. Herynk, M.H.; Fuqua, S.A.W. Estrogen receptors in resistance to hormone therapy. Adv. Exp. Med. Biol. 2007, 608, 130-143.

30. Lapidus, R.G.; Nass, S.J.; Davidson, N.E. The Loss of Estrogen and Progesterone Receptor Gene Expression in Human Breast Cancer. J. Mammary Gland Biol. Neoplasia 1998, 3, 85-94. [CrossRef]

31. Enmark, E.; Pelto-Huikko, M.; Grandien, K.; Lagercrantz, S.; Lagercrantz, J.; Fried, G.; Nordenskjöld, M.; Gustafsson, J.A. Human estrogen receptor $\beta$-gene structure, chromosomal localization, and expression pattern. J. Clin. Endocrinol. Metab. 1997, 82, 4258-4265. [CrossRef]

32. Mohammed, H.; Russell, I.A.; Stark, R.; Rueda, O.M.; Hickey, T.E.; Tarulli, G.A.; Serandour, A.A.A.; Birrell, S.N.; Bruna, A.; Saadi, A.; et al. Progesterone receptor modulates ER $\alpha$ action in breast cancer. Nature 2015, 523, 313-317. [CrossRef] [PubMed]

33. Cui, X.; Schiff, R.; Arpino, G.; Osborne, C.K.; Lee, A.V. Biology of progesterone receptor loss in breast cancer and its implications for endocrine therapy. J. Clin. Oncol. 2005, 23, 7721-7735. [CrossRef] [PubMed]

34. Tomlinson, I.P.M.; Nicolai, H.; Solomon, E.; Boomer, W.F. The frequency and mechanism of loss of heterozygosity on chromosome 11q in breast cancer. J. Pathol. 1996, 180, 38-43. [CrossRef]

35. Kangaspeska, S.; Stride, B.; Métivier, R.; Polycarpou-Schwarz, M.; Ibberson, D.; Carmouche, R.P.; Benes, V.; Gannon, F.; Reid, G. Transient cyclical methylation of promoter DNA. Nature 2008, 452, 112-115. [CrossRef] [PubMed]

36. Ottaviano, Y.L.; Issa, J.-P.; Parl, F.F.; Smith, H.S.; Baylin, S.B.; Davidson, N.E. Methylation of the Estrogen Receptor Gene CpG Island Marks Loss of Estrogen Receptor Expression in Human Breast Cancer Cells. Cancer Res. 1994, 54, 2552-2555. [PubMed]

37. Yang, X.; Phillips, D.L.; Ferguson, A.T.; Nelson, W.G.; Herman, J.G.; Davidson, N.E. Synergistic activation of functional estrogen receptor (ER)- $\alpha$ by DNA methyltransferase and histone deacetylase inhibition in human ER- $\alpha$-negative breast cancer cells. Cancer Res. 2001, 61, 7025-7029.

38. Tsuboi, K.; Nagatomo, T.; Gohno, T.; Higuchi, T.; Sasaki, S.; Fujiki, N.; Kurosumi, M.; Takei, H.; Yamaguchi, Y.; Niwa, T.; et al. Single CpG site methylation controls estrogen receptor gene transcription and correlates with hormone therapy resistance. J. Steroid Biochem. Mol. Biol. 2017, 171, 209-217. [CrossRef]

39. Zhang, J.; Zhou, C.; Jiang, H.; Liang, L.; Shi, W.; Zhang, Q.; Sun, P.; Xiang, R.; Wang, Y.; Yang, S. ZEB1 induces ER- $\alpha$ promoter hypermethylation and confers antiestrogen resistance in breast cancer. Cell Death Dis. 2017, 8, e2732. [CrossRef]

40. Lapidus, R.G.; Ferguson, A.T.; Ottaviano, Y.L.; Parl, F.F.; Smith, H.S.; Weitzman, S.A.; Baylin, S.B.; Issa, J.P.J.; Davidson, N.E. Methylation of estrogen and progesterone receptor gene 5' CpG islands correlates with lack of estrogen and progesterone receptor gene expression in breast tumors. Clin. Cancer Res. 1996, 2, 805-810.

41. Leu, Y.W.; Yan, P.S.; Fan, M.; Jin, V.X.; Liu, J.C.; Curran, E.M.; Welshons, W.V.; Wei, S.H.; Davuluri, R.V.; Plass, C.; et al. Loss of estrogen receptor signaling triggers epigenetic silencing of downstream targets in breast cancer. Cancer Res. 2004, 64, 8184-8192. [CrossRef]

42. Perren, A.; Weng, L.P.; Boag, A.H.; Ziebold, U.; Thakore, K.; Dahia, P.L.M.; Komminoth, P.; Lees, J.A.; Mulligan, L.M.; Mutter, G.L.; et al. Immunohistochemical evidence of loss of PTEN expression in primary ductal adenocarcinomas of the breast. Am. J. Pathol. 1999, 155, 1253-1260. [CrossRef]

43. Garcia, J.M.; Silva, J.M.; Dominguez, G.; Gonzalez, R.; Navarro, A.; Carretero, L.; Provencio, M.; España, P.; Bonilla, F. Allelic loss of the PTEN region (10q23) in breast carcinomas of poor pathophenotype. Breast Cancer Res. Treat. 1999, 57, 237-243. [CrossRef] [PubMed] 
44. Cui, X.; Zhang, P.; Deng, W.; Oesterreich, S.; Lu, Y.; Mills, G.B.; Lee, A.V. Insulin-like growth factor-I inhibits progesterone receptor expression in breast cancer cells via the phosphatidylinositol 3-kinase/Akt/mammalian target of rapamycin pathway: Progesterone receptor as a potential indicator of growth factor activity in breast cancer. Mol. Endocrinol. 2003, 17, 575-588. [PubMed]

45. Oh, A.S.; Lorant, L.A.; Holloway, J.N.; Miller, D.L.; Kern, F.G.; El-Ashry, D. Hyperactivation of MAPK Induces Loss of ER $\alpha$ Expression in Breast Cancer Cells. Mol. Endocrinol. 2001, 15, 1344-1359. [CrossRef]

46. Sheikh, M.S.; Shao, Z.-M.; Chen, J.-C.; Li, X.-S.; Hussain, A.; Fontana, J.A. Expression of estrogen receptors in estrogen receptor-negative human breast carcinoma cells: Modulation of epidermal growth factor-receptor (EGF-R) and transforming growth factor $\alpha$ (TGF $\alpha)$ gene expression. J. Cell. Biochem. 1994, 54, $289-298$. [CrossRef]

47. Montemurro, F.; Di Cosimo, S.; Arpino, G. Human epidermal growth factor receptor 2 (her2)-positive and hormone receptor-positive breast cancer: New insights into molecular interactions and clinical implications. Ann. Oncol. 2013, 24, 2715-2724. [CrossRef]

48. Guo, S.; Sonenshein, G.E. Forkhead Box Transcription Factor FOXO3a Regulates Estrogen Receptor Alpha Expression and Is Repressed by the Her-2/neu/Phosphatidylinositol 3-Kinase/Akt Signaling Pathway. Mol. Cell. Biol. 2004, 24, 8681-8690. [CrossRef]

49. Lal, P.; Tan, L.K.; Chen, B. Correlation of HER-2 Status With Estrogen and Progesterone Receptors and Histologic Features in 3,655 Invasive Breast Carcinomas. Am. J. Clin. Pathol. 2005, 123, 541-546. [CrossRef]

50. Creighton, C.J.; Hilger, A.M.; Murthy, S.; Rae, J.M.; Chinnaiyan, A.M.; El-Ashry, D. Activation of mitogen-activated protein kinase in estrogen receptor $\alpha$-positive breast cancer cells in vitro induces an in vivo molecular phenotype of estrogen receptor $\alpha$-negative human breast tumors. Cancer Res. 2006, 66, 3903-3911. [CrossRef]

51. Zhou, Y.; Eppenberger-Castori, S.; Eppenberger, U.; Benz, C.C. The NFkB pathway and endocrine-resistant breast cancer. Endocr. Relat. Cancer 2005, 12, S37-S46. [CrossRef]

52. Zhou, Y.; Eppenberger-Castori, S.; Marx, C.; Yau, C.; Scott, G.K.; Eppenberger, U.; Benz, C.C. Activation of nuclear factor- $\mathrm{kB}(\mathrm{NF \kappa} \mathrm{B})$ identifies a high-risk subset of hormone-dependent breast cancers. Int. J. Biochem. Cell Biol. 2005, 37, 1130-1144. [CrossRef] [PubMed]

53. Holloway, J.N.; Murthy, S.; El-Ashry, D. A cytoplasmic substrate of mitogen-activated protein kinase is responsible for estrogen receptor- $\alpha$ down-regulation in breast cancer cells: The role of nuclear factor- $\mathrm{kB}$. Mol. Endocrinol. 2004, 18, 1396-1410. [CrossRef] [PubMed]

54. Pianetti, S.; Arsura, M.; Romieu-Mourez, R.; Coffey, R.J.; Sonenshein, G.E. Her-2/neu overexpression induces NF- $\kappa$ B via a PI3-kinase/Akt pathway involving calpain-mediated degradation of IкB- $\alpha$ that can be inhibited by the tumor suppressor PTEN. Oncogene 2001, 20, 1287-1299. [CrossRef] [PubMed]

55. Garrido-Castro, A.C.; Lin, N.U.; Polyak, K. Insights into molecular classifications of triple-negative breast cancer: Improving patient selection for treatment. Cancer Discov. 2019, 9, 176-198. [CrossRef] [PubMed]

56. Kenealy, M.R.; Flouriot, G.; Sonntag-Buck, V.; Dandekar, T.; Brand, H.; Gannon, F. The 3'-untranslated region of the human estrogen receptor $\alpha$ gene mediates rapid messenger ribonucleic acid turnover. Endocrinology 2000, 141, 2805-2813. [CrossRef]

57. Carmeci, C.; DeConinck, E.C.; Lawton, T.; Bloch, D.A.; Weigel, R.J. Analysis of estrogen receptor messenger RNA in breast carcinomas from archival specimens is predictive of tumor biology. Am. J. Pathol. 1997, 150, 1563-1570.

58. Liang, Y.K.; Lin, H.Y.; Dou, X.W.; Chen, M.; Wei, X.L.; Zhang, Y.Q.; Wu, Y.; Chen, C.F.; Bai, J.W.; Xiao, Y.S.; et al. MiR-221/222 promote epithelial-mesenchymal transition by targeting Notch3 in breast cancer cell lines. NPJ Breast Cancer 2018, 4, 1-9. [CrossRef]

59. Al-Nakhle, H.; Burns, P.A.; Cummings, M.; Hanby, A.M.; Hughes, T.A.; Satheesha, S.; Shaaban, A.M.; Smith, L.; Speirs, V. Estrogen receptor $\beta 1$ expression is regulated by miR-92 in breast cancer. Cancer Res. 2010, 70, 4778-4784. [CrossRef]

60. Li, X.; Mertens-Talcott, S.U.; Zhang, S.; Kim, K.H.; Ball, J.; Safe, S. MicroRNA-27a indirectly regulates estrogen receptor $\alpha$ expression and hormone responsiveness in MCF-7 breast cancer cells. Endocrinology 2010, 151, 2462-2473. [CrossRef]

61. Tecalco-Cruz, A.C.; Ramírez-Jarquín, J.O. Mechanisms that Increase Stability of Estrogen Receptor Alpha in Breast Cancer. Clin. Breast Cancer 2017, 17, 1-10. [CrossRef] 
62. Osborne, C.K.; Wakeling, A.; Nicholson, R.I. Fulvestrant: An oestrogen receptor antagonist with a novel mechanism of action. Br. J. Cancer 2004, 90, S2-S6. [CrossRef] [PubMed]

63. Wardell, S.E.; Marks, J.R.; McDonnell, D.P. The turnover of estrogen receptor $\alpha$ by the selective estrogen receptor degrader (SERD) fulvestrant is a saturable process that is not required for antagonist efficacy. Biochem. Pharmacol. 2011, 82, 122-130. [CrossRef] [PubMed]

64. Guan, J.; Zhou, W.; Hafner, M.; Blake, R.A.; Chalouni, C.; Chen, I.P.; De Bruyn, T.; Giltnane, J.M.; Hartman, S.J.; Heidersbach, A.; et al. Therapeutic Ligands Antagonize Estrogen Receptor Function by Impairing Its Mobility. Cell 2019, 178, 949-963. [CrossRef] [PubMed]

65. Castoria, G.; Giovannelli, P.; Lombardi, M.; De Rosa, C.; Giraldi, T.; De Falco, A.; Barone, M.V.; Abbondanza, C.; Migliaccio, A.; Auricchio, F. Tyrosine phosphorylation of estradiol receptor by Src regulates its hormone-dependent nuclear export and cell cycle progression in breast cancer cells. Oncogene 2012, 31, 4868-4877. [CrossRef]

66. Kufe, D.W. MUC1-C oncoprotein as a target in breast cancer: Activation of signaling pathways and therapeutic approaches. Oncogene 2013, 32, 1073-1081. [CrossRef]

67. Rajbhandari, P.; Schalper, K.A.; Solodin, N.M.; Ellison-Zelski, S.J.; Ping Lu, K.; Rimm, D.L.; Alarid, E.T. Pin1 modulates ER $\alpha$ levels in breast cancer through inhibition of phosphorylation-dependent ubiquitination and degradation. Oncogene 2014, 33, 1438-1447. [CrossRef]

68. Caligiuri, I.; Rizzolio, F.; Boffo, S.; Giordano, A.; Toffoli, G. Critical choices for modeling breast cancer in transgenic mouse models. J. Cell Physiol. 2012, 227, 2988-2991. [CrossRef]

69. Zhu, J.; Zhao, C.; Kharman-Biz, A.; Zhuang, T.; Jonsson, P.; Liang, N.; Williams, C.; Lin, C.Y.; Qiao, Y.; Zendehdel, K.; et al. The atypical ubiquitin ligase RNF31 stabilizes estrogen receptor $\alpha$ and modulates estrogen-stimulated breast cancer cell proliferation. Oncogene 2014, 33, 4340-4351. [CrossRef]

70. la Rosa, P.; Pesiri, V.; Leclercq, G.; Marino, M.; Acconcia, F. Palmitoylation regulates 17 $\beta$-estradiol-induced estrogen receptor- $\alpha$ degradation and transcriptional activity. Mol. Endocrinol. 2012, 26, 762-774. [CrossRef]

71. Bhandari, V.; Hoey, C.; Liu, L.Y.; Lalonde, E.; Ray, J.; Livingstone, J.; Lesurf, R.; Shiah, Y.J.; Vujcic, T.; Huang, X.; et al. Molecular landmarks of tumor hypoxia across cancer types. Nat. Genet. 2019, 51, 308-318. [CrossRef]

72. Stoner, M.; Saville, B.; Wormke, M.; Dean, D.; Burghardt, R.; Safe, S. Hypoxia induces proteasome-dependent degradation of estrogen receptor $\alpha$ in ZR-75 breast cancer cells. Mol. Endocrinol. 2002, 16, 2231-2242. [CrossRef] [PubMed]

73. Ryu, K.; Park, C.; Lee, Y.J. Hypoxia-inducible factor 1 alpha represses the transcription of the estrogen receptor alpha gene in human breast cancer cells. Biochem. Biophys. Res. Commun. 2011, 407, 831-836. [CrossRef] [PubMed]

74. Wolff, M.; Kosyna, F.K.; Dunst, J.; Jelkmann, W.; Depping, R. Impact of hypoxia inducible factors on estrogen receptor expression in breast cancer cells. Arch. Biochem. Biophys. 2017, 613, 23-30. [CrossRef] [PubMed]

75. Militello, A.M.; Zielli, T.; Boggiani, D.; Michiara, M.; Naldi, N.; Bortesi, B.; Zanelli, P.; Uliana, V.; Giuliotti, S.; Musolino, A. Mechanism of action and clinical efficacy of CDK4/6 inhibitors in BRCA-mutated, estrogen receptor-positive breast cancers: Case report and literature review. Front. Oncol. 2019, 9, 759. [CrossRef]

76. Goodwin, P.J.; Phillips, K.A.; West, D.W.; Ennis, M.; Hopper, J.L.; John, E.M.; O’Malley, F.P.; Milne, R.L.; Andrulis, I.L.; Friedlander, M.L.; et al. Breast cancer prognosis in BRCA1 and BRCA2 mutation carriers: An international prospective breast cancer family registry population-based cohort study. J. Clin. Oncol. 2012, 30, 19-26. [CrossRef]

77. Anderson, S.F.; Schlegel, B.P.; Nakajima, T.; Wolpin, E.S.; Parvin, J.D. BRCA1 protein is linked to the RNA polymerase II holoenzyme complex via RNA helicase A. Nat. Genet. 1998, 19, 254-256. [CrossRef] [PubMed]

78. Hosey, A.M.; Gorski, J.J.; Murray, M.M.; Quinn, J.E.; Chung, W.Y.; Stewart, G.E.; James, C.R.; Farragher, S.M.; Mulligan, J.M.; Scott, A.N.; et al. Molecular basis for estrogen receptor $\alpha$ deficiency in BRCA1-linked breast cancer. J. Natl. Cancer Inst. 2007, 99, 1683-1694. [CrossRef]

79. Roldán, G.; Delgado, L.; Musé, I.M. Tumoral expression of BRCA1, estrogen receptor alpha and ID4 protein in patients with sporadic breast cancer. Cancer Biol. Ther. 2006, 5, 505-510. [CrossRef]

80. Calvo, V.; Beato, M. BRCA1 counteracts progesterone action by ubiquitination leading to progesterone receptor degradation and epigenetic silencing of target promoters. Cancer Res. 2011, 71, 3422-3431. [CrossRef]

81. Kuukasjärvi, T.; Kononen, J.; Helin, H.; Holli, K.; Isola, J. Loss of estrogen receptor in recurrent breast cancer is associated with poor response to endocrine therapy. J. Clin. Oncol. 1996, 14, 2584-2589. [CrossRef] 
82. Horwitz, K.B.; Smith, J.A.; Jewett, P.B.; Horwitz, K.B. Heterogeneity of Progesterone Receptor Content and Remodeling by Tamoxifen Characterize Subpopulations of Cultured Human Breast Cancer Cells: Analysis by Quantitative Dual Parameter Flow Cytometry. Cancer Res. 1992, 52, 593-602.

83. Annaratone, L.; Simonetti, M.; Wernersson, E.; Marchiò, C.; Garnerone, S.; Scalzo, M.S.; Bienko, M.; Chiarle, R.; Sapino, A.; Crosetto, N. Quantification of HER2 and estrogen receptor heterogeneity in breast cancer by single-molecule RNA fluorescence in situ hybridization. Oncotarget 2017, 8, 18680-18698. [CrossRef] [PubMed]

84. Lindström, L.S.; Yau, C.; Czene, K.; Thompson, C.K.; Hoadley, K.A.; Van't Veer, L.J.; Balassanian, R.; Bishop, J.W.; Carpenter, P.M.; Chen, Y.Y.; et al. Intratumor heterogeneity of the estrogen receptor and the long-term risk of fatal Breast cancer. J. Natl. Cancer Inst. 2018, 110, 726-733. [CrossRef] [PubMed]

85. Davis, B.W.; Zava, D.T.; Locher, G.W.; Goldhirsch, A.; Hartmann, W.H. Receptor heterogeneity of human breast cancer as measured by multiple intratumoral assays of estrogen and progesterone receptor. Eur. J. Cancer Clin. Oncol. 1984, 20, 375-382. [CrossRef]

86. Chung, G.G.; Zerkowski, M.P.; Ghosh, S.; Camp, R.L.; Rimm, D.L. Quantitative analysis of estrogen receptor heterogeneity in breast cancer. Lab. Investig. 2007, 87, 662-669. [CrossRef] [PubMed]

87. Allott, E.H.; Geradts, J.; Sun, X.; Cohen, S.M.; Zirpoli, G.R.; Khoury, T.; Bshara, W.; Chen, M.; Sherman, M.E.; Palmer, J.R.; et al. Intratumoral heterogeneity as a source of discordance in breast cancer biomarker classification. Breast Cancer Res. 2016, 18, 1-11. [CrossRef]

88. Zhang, L.; Riethdorf, S.; Wu, G.; Wang, T.; Yang, K.; Peng, G.; Liu, J.; Pantel, K. Meta-analysis of the prognostic value of circulating tumor cells in breast cancer. Clin. Cancer Res. 2012, 18, 5701-5710. [CrossRef]

89. Babayan, A.; Hannemann, J.; Spötter, J.; Müller, V.; Pantel, K.; Joosse, S.A. Heterogeneity of Estrogen Receptor Expression in Circulating Tumor Cells from Metastatic Breast Cancer Patients. PLoS ONE 2013, 8, e75038. [CrossRef]

90. Lindstrom, L.S.; Karlsson, E.; Wilking, U.M.; Johansson, U.; Hartman, J.; Lidbrink, E.K.; Hatschek, T.; Skoog, L.; Bergh, J.; Lindström, L.S.; et al. Clinically used breast cancer markers such as estrogen receptor, progesterone receptor, and human epidermal growth factor receptor 2 are unstable throughout tumor progression. J. Clin. Oncol. 2012, 30, 2601-2608. [CrossRef]

91. Arnedos, M.; Nerurkar, A.; Osin, P.; A'Hern, R.; Smith, I.E.; Dowsett, M. Discordance between core needle biopsy (CNB) and excisional biopsy (EB) for estrogen receptor (ER), progesterone receptor (PgR) and HER2 status in early breast cancer (EBC). Ann. Oncol. Off. J. Eur. Soc. Med. Oncol. 2009, 20, 1948-1952. [CrossRef]

92. Jensen, J.D.; Knoop, A.; Ewertz, M.; Laenkholm, A.-V.V. ER, HER2, and TOP2A expression in primary tumor, synchronous axillary nodes, and asynchronous metastases in breast cancer. Breast Cancer Res. Treat. 2012, 132, 511-521. [CrossRef] [PubMed]

93. Aitken, S.J.; Thomas, J.S.; Langdon, S.P.; Harrison, D.J.; Faratian, D. Quantitative analysis of changes in ER, PR and HER2 expression in primary breast cancer and paired nodal metastases. Ann. Oncol. Off. J. Eur. Soc. Med. Oncol. 2010, 21, 1254-1261. [CrossRef] [PubMed]

94. Allison, K.H.; Hammond, M.E.H.; Dowsett, M.; McKernin, S.E.; Carey, L.A.; Fitzgibbons, P.L.; Hayes, D.F.; Lakhani, S.R.; Chavez-MacGregor, M.; Perlmutter, J.; et al. Estrogen and progesterone receptor testing in breast cancer: ASCO/CAP guideline update. J. Clin. Oncol. 2020, 38, 1346-1366. [CrossRef] [PubMed]

95. Uy, G.; Laudico, A.; Carnate, J.; Lim, F.; Fernandez, A.; Rivera, R.; Mapua, C.; Love, R. Breast cancer hormone receptor assay results of core needle biopsy and modified radical mastectomy specimens from the same patients. Clin. Breast Cancer 2010, 10, 154-159. [CrossRef] [PubMed]

96. Viale, G.; Regan, M.M.; Maiorano, E.; Mastropasqua, M.G.; Dell'Orto, P.; Rasmussen, B.B.; Raffoul, J.; Neven, P.; Orosz, Z.; Braye, S.; et al. Prognostic and predictive value of centrally reviewed expression of estrogen and progesterone receptors in a randomized trial comparing letrozole and tamoxifen adjuvant therapy for postmenopausal early breast cancer: BIG 1-98. J. Clin. Oncol. 2007, 25, 3846-3852. [CrossRef]

97. Zeng, J.; Piscuoglio, S.; Aggarwal, G.; Magda, J.; Friedlander, M.A.; Murray, M.; Akram, M.; Reis-Filho, J.S.; Weigelt, B.; Edelweiss, M. Hormone receptor and HER2 assessment in breast carcinoma metastatic to bone: A comparison between FNA cell blocks and decalcified core needle biopsies. Cancer Cytopathol. 2020, 128, 133-145. [CrossRef]

98. Wu, Y.T.; Li, X.; Lu, L.J.; Gan, L.; Dai, W.; Shi, Y.L.; Adhikari, V.P.; Wu, K.N.; Kong, L.Q. Effect of neoadjuvant chemotherapy on the expression of hormone receptors and Ki67 in Chinese breast cancer patients: A retrospective study of 525 patients. J. Biomed. Res. 2018, 32, 191-197. 
99. Hirata, T.; Shimizu, C.; Yonemori, K.; Hirakawa, A.; Kouno, T.; Tamura, K.; Ando, M.; Katsumata, N.; Fujiwara, Y. Change in the hormone receptor status following administration of neoadjuvant chemotherapy and its impact on the long-term outcome in patients with primary breast cancer. Br. J. Cancer 2009, 101, 1529-1536. [CrossRef]

100. Colleoni, M.; Viale, G.; Zahrieh, D.; Pruneri, G.; Gentilini, O.; Veronesi, P.; Gelber, R.D.; Curigliano, G.; Torrisi, R.; Luini, A.; et al. Chemotherapy is more effective in patients with breast cancer not expressing steroid hormone receptors: A study of preoperative treatment. Clin. Cancer Res. 2004, 10, 6622-6628. [CrossRef]

101. von Minckwitz, G.; Huang, C.-S.; Mano, M.S.; Loibl, S.; Mamounas, E.P.; Untch, M.; Wolmark, N.; Rastogi, P.; Schneeweiss, A.; Redondo, A.; et al. Trastuzumab Emtansine for Residual Invasive HER2-Positive Breast Cancer. N. Engl. J. Med. 2019, 380, 617-628. [CrossRef]

102. Masuda, N.; Lee, S.-J.; Ohtani, S.; Im, Y.-H.; Lee, E.-S.; Yokota, I.; Kuroi, K.; Im, S.-A.; Park, B.-W.; Kim, S.-B.; et al. Adjuvant Capecitabine for Breast Cancer after Preoperative Chemotherapy. N. Engl. J. Med. 2017, 376, 2147-2159. [CrossRef] [PubMed]

103. van de Ven, S.; Smit, V.T.H.B.M.H.B.M.; Dekker, T.J.A.A.; Nortier, J.W.R.R.; Kroep, J.R. Discordances in ER, PR and HER2 receptors after neoadjuvant chemotherapy in breast cancer. Cancer Treat. Rev. 2011, 37, 422-430. [CrossRef] [PubMed]

104. Tacca, O.; Penault-Llorca, F.; Abrial, C.; Mouret-Reynier, M.; Raoelfils, I.I.I.; Durando, X.; Achard, J.-L.J.; Gimbergues, P.; Curé, H.; Chollet, P.; et al. Changes in and Prognostic Value of Hormone Receptor Status in a Series of Operable Breast Cancer Patients Treated with Neoadjuvant Chemotherapy. Oncologist 2007, 12, 636-643. [CrossRef] [PubMed]

105. Chen, S.; Chen, C.-M.M.; Yu, K.-D.D.; Zhou, R.-J.J.; Shao, Z.-M.M. Prognostic value of a positive-to-negative change in hormone receptor status after neoadjuvant chemotherapy in patients with hormone receptorpositive breast cancer. Ann. Surg. Oncol. 2012, 19, 3002-3011. [CrossRef]

106. Jin, X.; Jiang, Y.Z.; Chen, S.; Yu, K.D.; Shao, Z.M.; Di, G.H. Prognostic value of receptor conversion after neoadjuvant chemotherapy in breast cancer patients: A prospective observational study. Oncotarget 2015, 6, 9600-9611. [CrossRef] [PubMed]

107. Lim, S.K.; Lee, M.H.; Park, I.H.; You, J.Y.; Nam, B.-H.; Kim, B.N.; Ro, J.; Lee, K.S.; Jung, S.-Y.; Kwon, Y.M.; et al. Impact of Molecular Subtype Conversion of Breast Cancers after Neoadjuvant Chemotherapy on Clinical Outcome. Cancer Res. Treat. 2016, 48, 133-141. [CrossRef]

108. Ding, Y.; Ding, K.; Qian, H.; Yu, X.; Zou, D.; Yang, H.; Mo, W.; He, X.; Zhang, F.; Qin, C.; et al. Impact on survival of estrogen receptor, progesterone receptor and $\mathrm{Ki}-67$ expression discordance pre- and post-neoadjuvant chemotherapy in breast cancer. PLoS ONE 2020, 15, e0231895. [CrossRef]

109. Allevi, G.; Strina, C.; Andreis, D.; Zanoni, V.; Bazzola, L.; Bonardi, S.; Foroni, C.; Milani, M.; Cappelletti, M.R.; Gussago, F.; et al. Increased pathological complete response rate after a long-term neoadjuvant letrozole treatment in postmenopausal oestrogen and/or progesterone receptor-positive breast cancer. Br. J. Cancer 2013, 108, 1587-1592. [CrossRef]

110. Ellis, M.J.; Tao, Y.; Luo, J.; A’Hern, R.; Evans, D.B.; Bhatnagar, A.S.; Chaudri Ross, H.A.; Von Kameke, A.; Miller, W.R.; Smith, I.; et al. Outcome prediction for estrogen receptor-positive breast cancer based on postneoadjuvant endocrine therapy tumor characteristics. J. Natl. Cancer Inst. 2008, 100, 1380-1388. [CrossRef]

111. Hawkins, R.A.; Tesdale, L.; Anderson, E.D.C.; Levack, P.A.; Chetty, U.; Forrest, A.P.M. Does the oestrogen receptor concentration of a breast cancer change during systemic therapy? Br. J. Cancer 1990, 61, 877-880. [CrossRef]

112. Miller, W.R.; Dixon, J.M.; Macfarlane, L.; Cameron, D.; Anderson, T.J. Pathological features of breast cancer response following neoadjuvant treatment with either letrozole or tamoxifen. Eur. J. Cancer 2003, 39, 462-468. [CrossRef]

113. Berry, D.A.; Cronin, K.A.; Plevritis, S.K.; Fryback, D.G.; Clarke, L.; Zelen, M.; Mandelblatt, J.S.; Yakovlev, A.Y.; Habbema, J.D.F.; Feuer, E.J. Effect of Screening and Adjuvant Therapy on Mortality from Breast Cancer. N. Engl. J. Med. 2005, 353, 1784-1792. [CrossRef] [PubMed]

114. Abe, O.; Abe, R.; Enomoto, K.; Kikuchi, K.; Koyama, H.; Masuda, H.; Nomura, Y.; Sakai, K.; Sugimachi, K.; Tominaga, T.; et al. Effects of chemotherapy and hormonal therapy for early breast cancer on recurrence and 15-year survival: An overview of the randomised trials. Lancet 2005, 365, 1687-1717. 
115. Simmons, C.; Miller, N.; Geddie, W.; Gianfelice, D.; Oldfield, M.; Dranitsaris, G.; Clemons, M.J. Does confirmatory tumor biopsy alter the management of breast cancer patients with distant metastases? Ann. Oncol. Off. J. Eur. Soc. Med. Oncol. 2009, 20, 1499-1504. [CrossRef] [PubMed]

116. Amir, E.; Miller, N.; Geddie, W.; Freedman, O.; Kassam, F.; Simmons, C.; Oldfield, M.; Dranitsaris, G.; Tomlinson, G.; Laupacis, A.; et al. Prospective study evaluating the impact of tissue confirmation of metastatic disease in patients with breast cancer. J. Clin. Oncol. 2012, 30, 587-592. [CrossRef]

117. Dieci, M.V.; Barbieri, E.; Piacentini, F.; Ficarra, G.; Bettelli, S.; Dominici, M.; Conte, P.F.; Guarneri, V. Discordance in receptor status between primary and recurrent breast cancer has a prognostic impact: A single-institution analysis. Ann. Oncol. 2013, 24, 101-108. [CrossRef] [PubMed]

118. Lower, E.E.; Glass, E.L.; Bradley, D.A.; Blau, R.; Heffelfinger, S. Impact of metastatic estrogen receptor and progesterone receptor status on survival. Breast Cancer Res. Treat. 2005, 90, 65-70. [CrossRef]

119. Stueber, T.N.; Weiss, C.R.; Woeckel, A.; Haeusler, S. Influences of adjuvant treatments in hormone receptor positive breast cancer on receptor conversion in recurrent breast cancer. Arch. Gynecol. Obstet. 2019, 299, 533-541. [CrossRef]

120. Ongaro, E.; Gerratana, L.; Cinausero, M.; Pelizzari, G.; Poletto, E.; Giangreco, M.; Andreetta, C.; Pizzolitto, S.; Di Loreto, C.; Minisini, A.M.; et al. Comparison of primary breast cancer and paired metastases: Biomarkers discordance influence on outcome and therapy. Future Oncol. 2018, 14, 849-859. [CrossRef]

121. Liedtke, C.; Broglio, K.; Moulder, S.; Hsu, L.; Kau, S.W.; Symmans, W.F.; Albarracin, C.; Meric-Bernstam, F.; Woodward, W.; Theriault, R.L.; et al. Prognostic impact of discordance between triple-receptor measurements in primary and recurrent breast cancer. Ann. Oncol. 2009, 20, 1953-1958. [CrossRef]

122. Thompson, A.M.; Jordan, L.B.; Quinlan, P.; Anderson, E.; Skene, A.; Dewar, J.A.; Purdie, C.A. Prospective comparison of switches in biomarker status between primary and recurrent breast cancer: The Breast Recurrence In Tissues Study (BRITS). Breast Cancer Res. 2010, 12, R92. [CrossRef] [PubMed]

123. Paolillo, C.; Mu, Z.; Rossi, G.; Schiewer, M.J.; Nguyen, T.; Austin, L.; Capoluongo, E.; Knudsen, K.; Cristofanilli, M.; Fortina, P. Detection of activating estrogen receptor gene (ESR1) mutations in single circulating tumor cells. Clin. Cancer Res. 2017, 23, 6086-6093. [CrossRef] [PubMed]

124. Peterson, L.M.; Kurland, B.F.; Schubert, E.K.; Link, J.M.; Gadi, V.K.; Specht, J.M.; Eary, J.F.; Porter, P.; Shankar, L.K.; Mankoff, D.A.; et al. A phase 2 study of $16 \alpha-[18 \mathrm{~F}]$-fluoro-17 $\beta$-estradiol positron emission tomography (FES-PET) as a marker of hormone sensitivity in metastatic breast cancer (MBC). Mol. Imaging Biol. 2014, 16, 431-440. [CrossRef] [PubMed]

125. Wang, Y.; Ayres, K.L.; Goldman, D.A.; Dickler, M.N.; Bardia, A.; Mayer, I.A.; Winer, E.; Fredrickson, J.; Arteaga, C.L.; Baselga, J.; et al. 18F-fluoroestradiol PET/CT measurement of estrogen receptor suppression during a phase I trial of the novel estrogen receptor-targeted therapeutic GDC-0810: Using an imaging biomarker to guide drug dosage in subsequent trials. Clin. Cancer Res. 2017, 23, 3053-3060. [CrossRef]

126. Mortimer, J.E.; Dehdashti, F.; Siegel, B.A.; Trinkaus, K.; Katzenellenbogen, J.A.; Welch, M.J. Metabolic Flare: Indicator of Hormone Responsiveness in Advanced Breast Cancer. J. Clin. Oncol. 2001, 19, 2797-2803. [CrossRef]

127. Linden, H.M.; Stekhova, S.A.; Link, J.M.; Gralow, J.R.; Livingston, R.B.; Ellis, G.K.; Petra, P.H.; Peterson, L.M.; Schubert, E.K.; Dunnwald, L.K.; et al. Quantitative fluoroestradiol positron emission tomography imaging predicts response to endocrine treatment in breast cancer. J. Clin. Oncol. 2006, 24, 2793-2799. [CrossRef]

Publisher's Note: MDPI stays neutral with regard to jurisdictional claims in published maps and institutional affiliations.

(C) 2020 by the authors. Licensee MDPI, Basel, Switzerland. This article is an open access article distributed under the terms and conditions of the Creative Commons Attribution (CC BY) license (http://creativecommons.org/licenses/by/4.0/). 